\title{
العنف اللفظي الممارس تجاه الطلبة المراهقين \\ (دراسة ميدانية مطبقة على عينة من طلبة التعليم ما بعد الأساسي \\ بمدارس محافظة مسقط - سلطنة عمان)
}

\author{
سالم محمد الغيلاني \\ كلية التربية جامعة محمد الخامس - الرياط - المملكة المغربية
}

مقدمة الدراسة ومشكلتها:

يمر الإنسان بالعديد من المر احل العمرية التي تتميز بالتطور والتجدد المستمرين، ومن أهم هذه المراحل: الطفولة

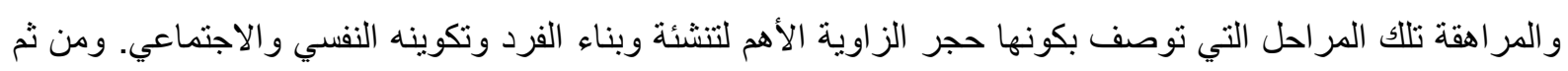
وجب الحرص و العناية عند التعامل مع الأفراد في هذه المراحل العمرية المهمة لتجنيب الأفراد (الأطفال) المخاطر الاجتماعية و النفسية التي يمكن ان يتعرضون لها منتجة آثار سلبية على الفرد و الأسرة و المجتمع.

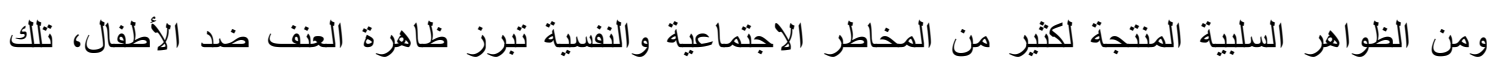
الظاهرة التي بينت وأكدت على وجودها الكثير من الدراسات العلمية والبحوث. وقد تعرضت كثير من هذه الدراسات لتناول هذه الظاهرة ومعالجنها بهدف الحد و التقليل من مخاطر ها المتعددة. ويعود اهتمام المجتمع الدولي بمحاربة العنف ضد الأطفال لعشرينيات القرن الماضي وتحديدا مع إعلان جنيف

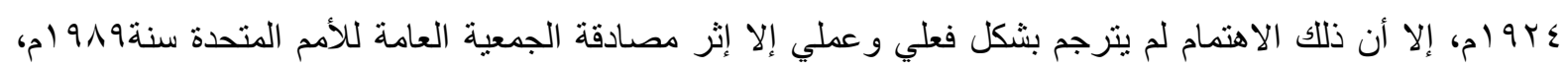



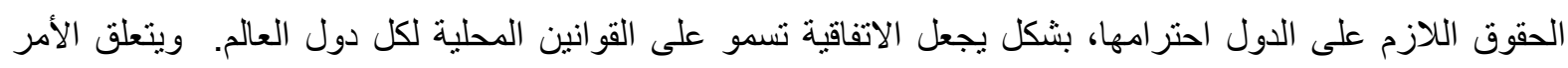

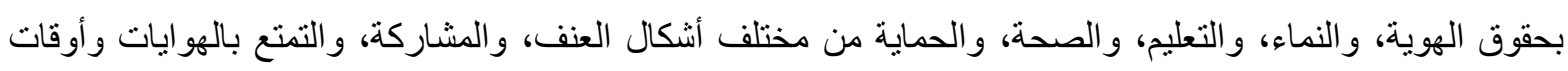

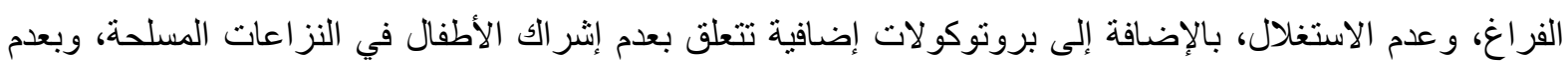

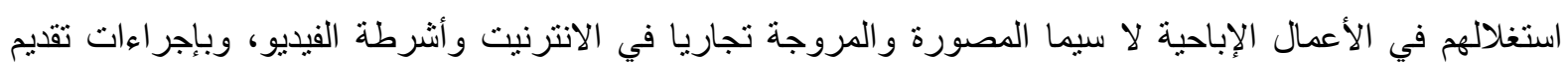

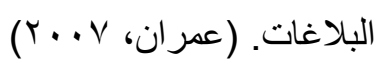

ويعد العنف " Violence " مشكلة وجودية منتشرة في جميع أنحاء العالم، وخاصة في البلدان النامية نظر اً لغياب الحريات الفكرية و الديمقراطية وغياب القانون على الرغم من الجهود المبذولة لمؤسسات المجتمع المدني ولجان الدفاع

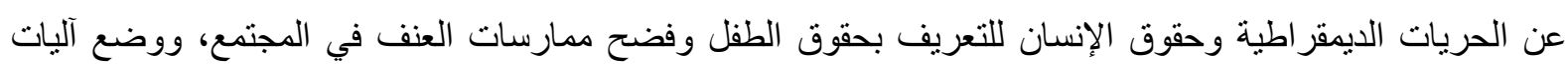
تربوية للحد من انتشاره. إلا أن هذه الجهود تصطدم بالكثير من المعوقات كالافتقار إلى مر اكز أبحاث تهنم بهذه الظاهرة

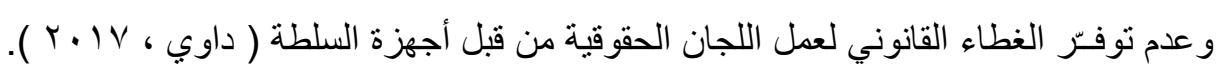

ومن المنظور العالمي تثير إحصاءات الامم المتحدة الى انتشار ظاهرة تعرض الأطفال للعنف وذللك من خلال تقرير "Paulo Sérgio Pinheiro " الذي أكد على ان العنف ضد الأطفال يحدث في كل مكان وفى كل دولة ومجتمع و عبر الجماعات الاجتماعية المختلفة وقد بين التقرير بعض الاحصاءات أهمها:

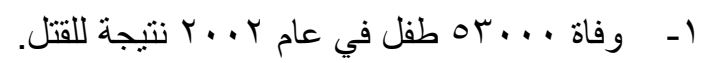

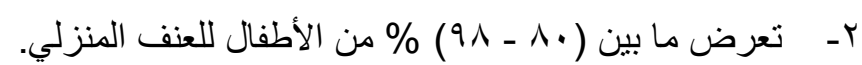




ع- - وفق تقدير منظمة الصحة العالمية فإن (10 (10) مليون فتاة و (VT) مليون طفل تحت سن الثامنة عشر تعرضوا للعنف الجنسي.

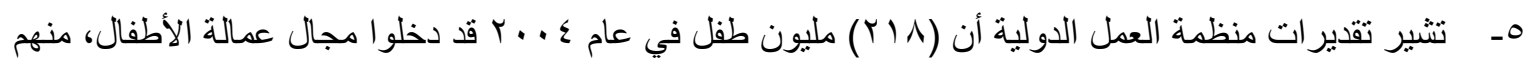
( آ Y ( ) مليون طفل في الأعمال الخطرة.

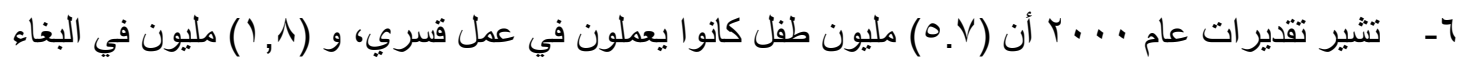

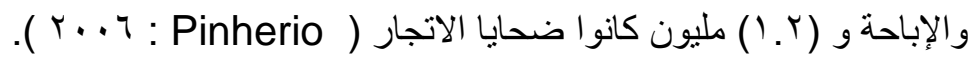

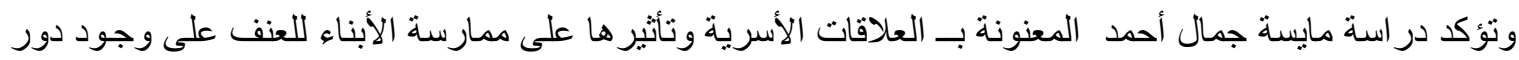
للأسرة في تكريس العنف لدى الأبناء، كما توصلت الدراسة الى عدة نتائج تؤدى الى اكساب الأبناء للعنف أهمها: الجو

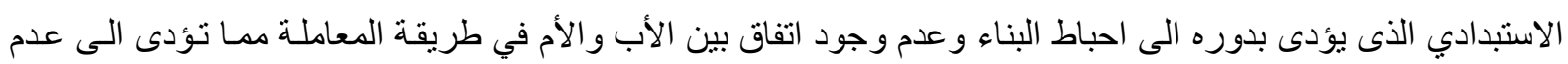

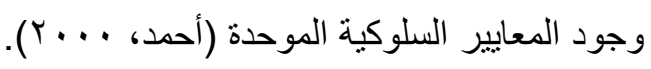
كما بينت در اسة شحاته أن من أكثر الأسباب المؤدية لعنف الطالب تمثلت في تعمد زملاء الطالب مضايقته، يليها

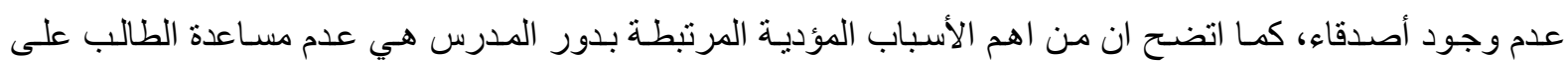
المذاكرة واستخدام أساليب غير ملائمة في توجيه الطالب، كذلك كان عدم رضـا الطالب عن النشاط المدرسي و المعاملـة



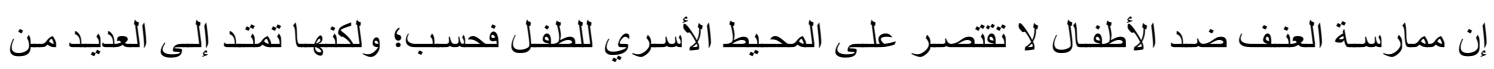
المؤسسات الاجتماعية الأخرى. وتعد الددرسة البيئة الاجتماعية الثانية بعد الأسرة و التي تسهم بشكل كبير في تشكيل حياة

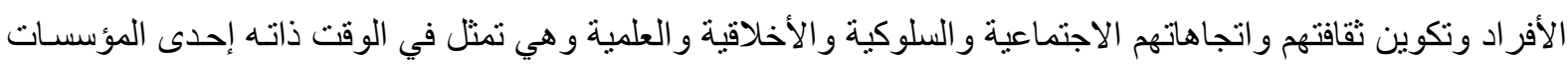

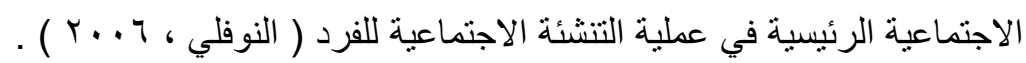

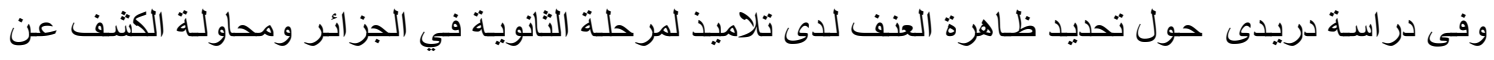
العو امل السوسيولوجية المؤدية الى عنف التلاميذ ودر اسة خصائص التلاميذ المعرضون للعنف المدرسي، انتهت الدراسة الى عدة نتائج مهمة، يمكن تلخيصها في تأزم الظروف العائلية والتحو لات المجتمعية المتسار عة، كما كثفت الدر اسة عن



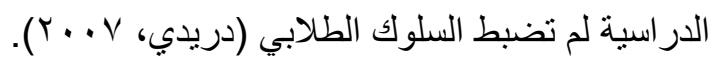
وقد يتولد العنف في المدارس نتيجة لمجموعة من العو امل منها: ضـغوط المعلمين، وضـوط البرنـامج الدراسي، و الثدة المفرطة، او التساهل المفرط في استخدام وسائل الضبط الاجتمـاعي داخل المدرسـة، أو التمييز في المعامل بين

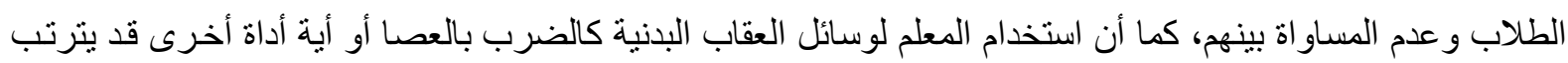
عليه ردة فعل تتسم بسلوك عنيف من جانب التلميذ. وفي در اسة سابقة لعزة عبد الجليل عبد العزيز عن مظـاهر إسـاءة معاملـة الأطفال و المر اهقين و العو امل المؤديـة

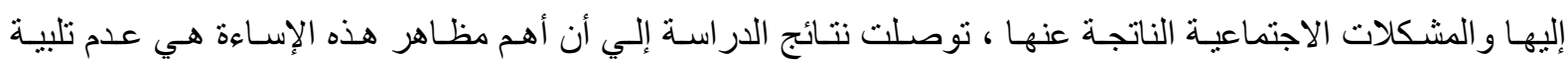
احتياجات الطفل أو المر اهق و عدم متابعته در اسيا وعدم الاهتمام بحديثه أو مر اقبـة علاقاته بأصدقائه ، وأن أهم العو امل الهل

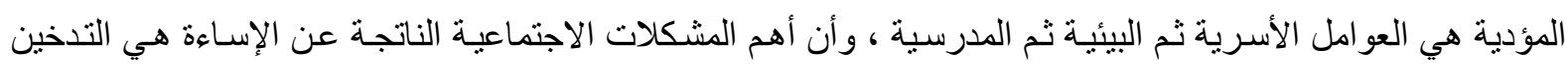
وتعاطي المخدرات وضعف الانتماء ثم ممارسة الطفل أو المر اهق لأعمال عشو ائية وعدم قدرته علي مو اجهة مشكلاته

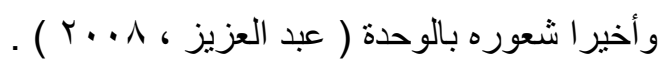


وفى إحدى الدراسات السابقة حول العنف أكدت على أن ارجاع بعض الأنماط العدوانية إلى فثل التلميذ في تحيق

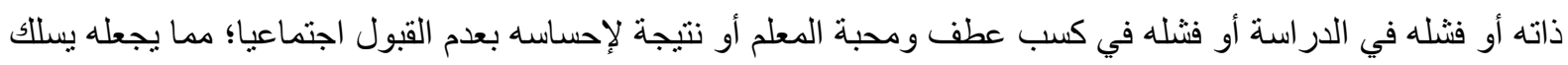

$$
\text { السلوك العدو اني كي يفرض ذاته ويعادى المجتمع و السلطة (النوفلي، و . . ب). }
$$

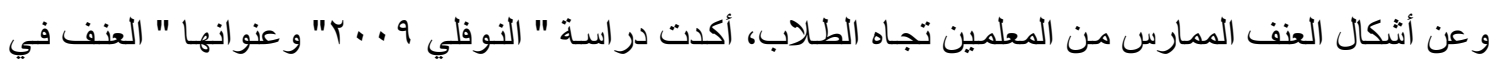

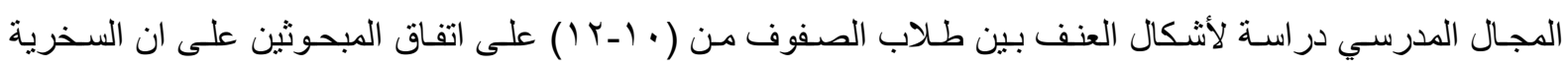

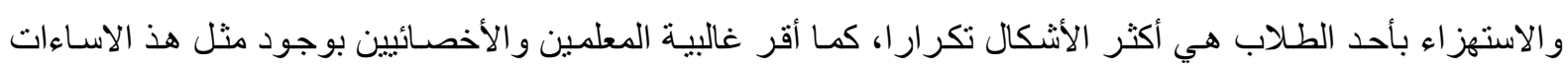
العنيفة ولكن بدرجة قليلة، كما اتى السب والثتم في الترتيب الثاني ومن وجهة نظر الطلاب والمعلمين، كما بينت نتائج

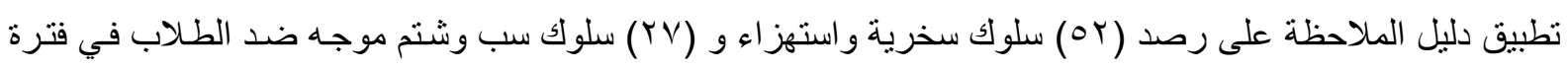

$$
\text { التطبيق (النوفلي، } 9 \text {. . ب). }
$$

و يرى الباحث أن هناك عدة عو امل تؤدى الى اكتساب الطلاب وخاصـة في مرحلـة المر اهقة الى السلوكيات التي

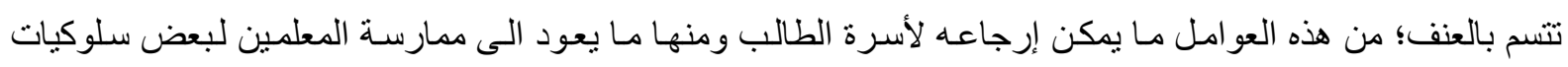

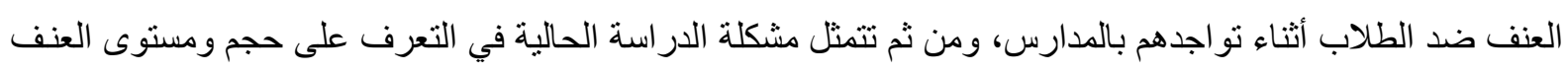

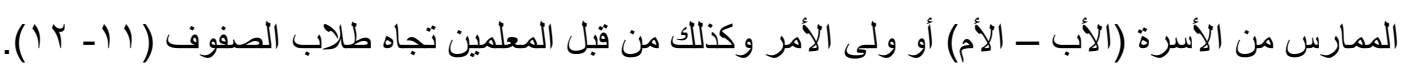
وفي ضوء ما سبق يمكن تحديد مشكلة الدر اسة الحالية في : دراسة العنف اللفظي الممارس تجاه الطلبة المر اهقين (در اسة الاسة ميدانية على عينة من طلبة التعليم ما بعد الأساسي بمدارس محافظة مسقط - سلطنة عمان).

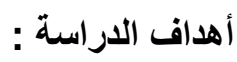
1. التعرف على مستوى العنف اللفظي الممارس من قبل ولي الأمر تجاه الطلبة المراهقين. r. التعرف على مستوى العنف اللفظي الممارس من قبل المعلم تجاه الطلبة المر اهقين. r. التعرف على تأثير بعض المتغيرات المستقلة للارسة مثل (النوع ومستوى تعليم ولى الأمر و عدد الأخوة ونمط السكن والصف الدراسي ....الخ) على مستوى العنف اللفظي الممارس من قبل ولي الأمر و المعلم تجاه

$$
\text { الطلبة المر اهقين. }
$$

\section{أهمية الدراسة:}

1- تتناول إحدى القضايا المهمة في معظم التخصصات الإنسانية والاجتماعية ألا وهي قضية العنف، نلك الظاهرة التي بدأت تتنتر بطريقة مخيفة وخطيرة في كافة المجتمعات ومن ثم وجب التعرف عليها وقياس مستوى ممارستها. r- ت توجيه الاهتمام لأحد أهم الفئات العمرية و أشدها خطورة في المجتمع الإنساني و هي فئة المر اهقين.

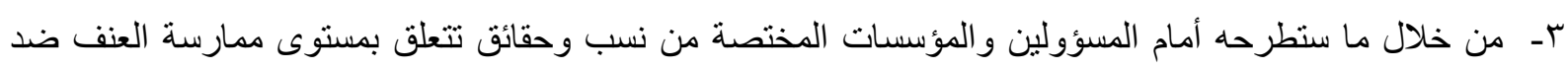

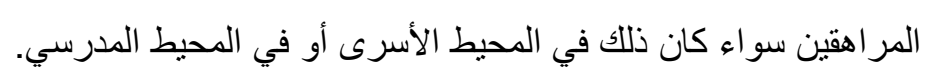

تساؤلات الاراسة:

$$
\begin{aligned}
& \text { ا -ما مستوى العنف اللفظي الذي يتعرض له الطلبة المر اهقين من قبل ولى الأمر (الأبـ الأم)؟ }
\end{aligned}
$$

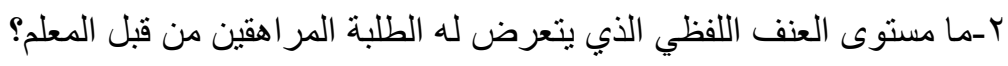

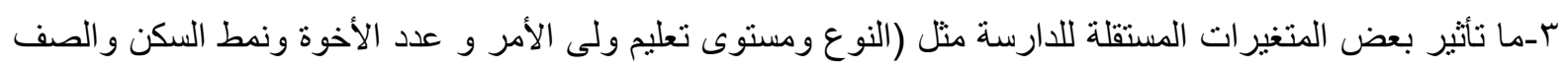

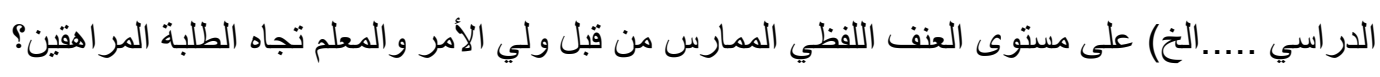


ا-توجد فروق احصائية ذات دلالة معنوية بيين العنف اللفظي الممارس من قبل ولى الأمر والعنف الممارس من قبل

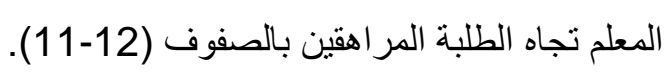
ז-توجد فروق احصائية ذات دلالة معنوية بين متوسطات درجات الطلبة المر اهقين على مقياس العنف اللفظي الموجه من ولي الأمر طبقا لمتغير النوع. ب-توجد فروق احصائية ذات دلالة معنوية بين متوسطات درجات الطلبة المر اهقين على مقياس العنف اللفظي الموجه من المعلم طبقا لمتغير النوع. ع-توجد فروق احصائية ذات دلالة معنوية في متوسطات درجات الطلبة المر اهقين على مقياس العنف اللفظي الموجه من ولي الامر و المعلم طبقا لمتغير الصف الدر اسي. هـتوجد فروق احصائية ذات دلالة معنوية بين متوسطات درجات الطلبة المر اهقين على مقياس العنف اللفظي الموجها من ولي الامر طبقا لمستواه التعليمي. 7-توجد فروق احصائية ذات دلالة معنوية بين متوسطات درجات الطلبة المر اهقين على مقياس العنف اللفظي الموجه من ولي الامر طبقا لحالته العملية. V-توجد فروق احصائية ذات دلالة معنوية بين متوسطات درجات الطلبة المر اهقين على مقياس العنف اللفظي الموجه من المعلم تجاههم طبقا لمستو اهم التحصيلي. مفاهيم الاراسة: مفهوم العنف Violence: المفهوم اللغوي للعنف في اللغة العربية يشير بوجه عام إلى كل سلوك يتضمن معاني الثدة

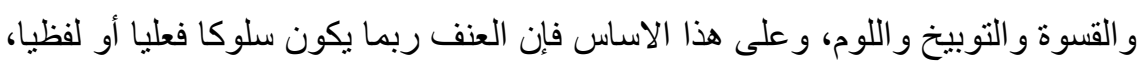

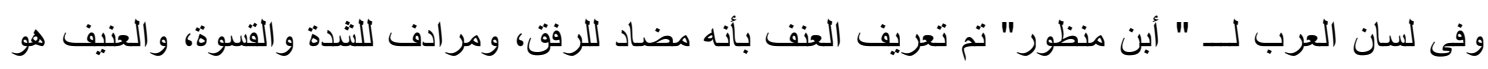
المنصف بالثدة، وعلى مستوى المصطلح، يقصد به "خرق بالأمر وقلة الرفق به، والعنف هو التوبيخ واللوم

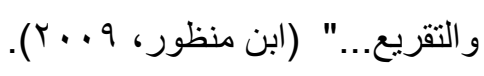

أما في اللغة الإنجليزية فان الأصل اللاتيني للكلمة Violence هو Violential، ومعناها الاستخدام غير

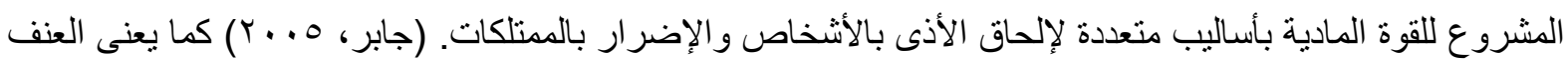
أيضا العمل بالخشونة ،و العنف أو التدنيس ، والانتهاك والمخالفة ، وكل هذه الكلمات ترنبط بكلمة " (Vis) التي تعني بالإني القوة و البأس، و القدرة، و العنف، وبدقة أكثر فإن كلمة (Vis) تعنى القوة الفاعلة و المؤثرة (كر اشة، و و . . ب).

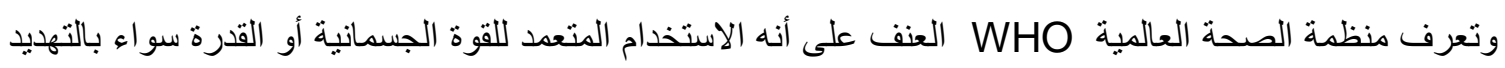
أو بالاستعمال الفعلي من قبل شخص ضد نفسه أو ضد شخص أخر أو ضد مجموعة أو مجتمع، بحيث يؤدي إلى -حدوث

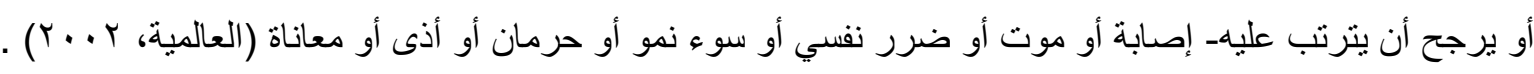

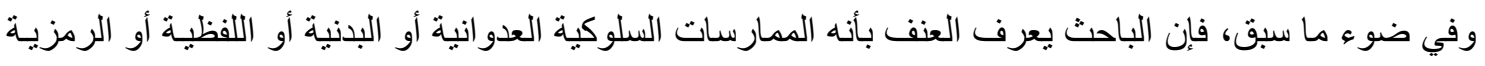

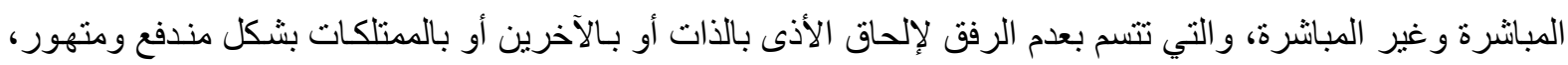
تغلب فيه قوة الجسم و السلطة اللسانية على قوة العقل و الأخلاقيات الإنسانية.

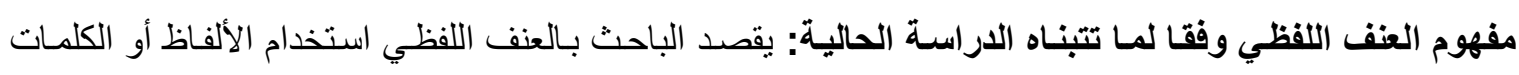
بغرض التقليل من فيمة وكر امة الطالب و التسبب في الحق الأذى والضر النفسي والمعنوي به وقد ينتج عن ذلك تأتيرات مباشرة وسريعة أوقد تحدث تأثير ات بعد فترة منمثلة في ظهور تغير ات واضحة وملموسة في سلوك الأخر وشخصيته 
مفهوم المراهقة Adolescence: تعرف المراهقة وفق معجم ويبستر Webster على أنها فترة الحياة التي ينمو

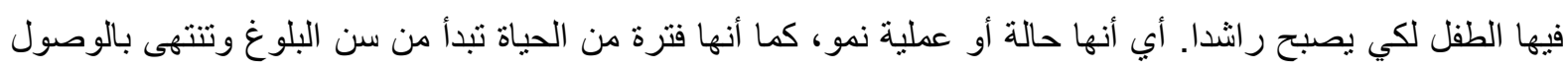
إلى مرحلة النضج، أي أنها مرحلة من مراحل النمو تسبق مرحلة النضج (Merriam-Webster, 2015). إلا أن

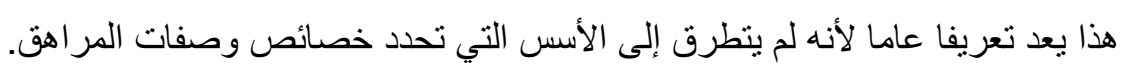
تبرز أهمية التعرف على خصائص المر اهقين من حيث كونهم يشكلون رقما مهما وكبير الها، فالعالم اليوم يعد وطنا

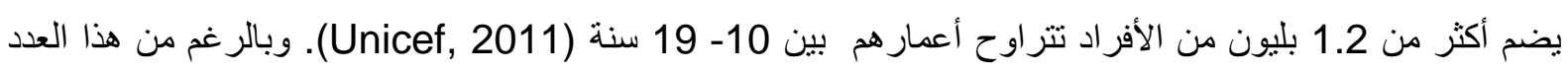
الكبير فإنه لا يوجد حاليا تعريف موحد للمر اهقين، وفي كثير من الأحيان يتم الاعتماد على العمر فقط في تحديد المقصود

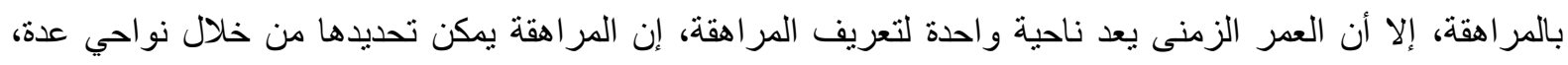

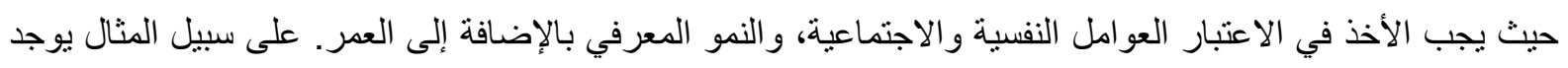
تعريف ينظر إلى للمر اهقة بوصفها الفترة الزمنية التي تبدأ من سن البلوغ حتى يحقق الفرد الاستقلال الاقتصادي، و والأهم هو وجوب الأخذ في الاعتبار بعناية حاجات و قدر ات كل مر اهق (APA, 2002).

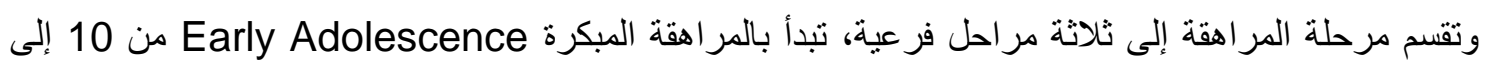
14 عام تقريبا، بينما تبدأ المراهقة المتوسطة Middle Adolescence من 15 إلى 16 عام تقريبا، والمراهقة المتأخرة Late Adolescence تبدأ من 17 إلى 21 عام تقريبا، ووفق هذا التصنيف الذي يقسم مرحلة المر اهقة الى لى ثلاث مر احل متتالية، فإن طلاب ما بعد التعليم الأساسي ـ و الذين يطبق عليهم البحث الحالي ـ يندرجون ضمن مرحلتي المر اهقة المتوسطة والمتأخرة. وفى هذا الإطار ترى "Sedra Spano " أن شعور وسلوك المر اهقين في المدارس

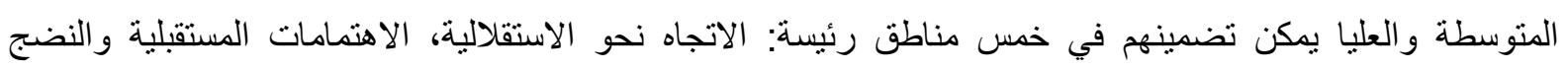

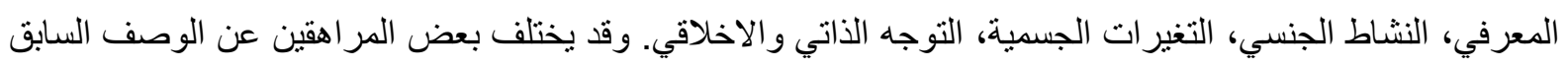
قليلا، لكن بشكل عام تكون السلوكيات و المشاعر نمطا ثابتا لكل مرحلة من مر احل المر اهقة (Spano, 2004). الاستراتيجية المنهجية للارسة لكنة

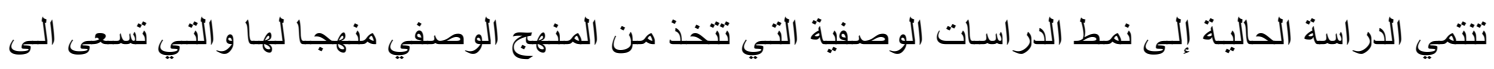
دراسة ووصف وتحليل الو اقع الحاضر لظاهرة العنف اللفظي الممارس من قبل ولى المر و المعلم تجاه الطلبة المر اهقين

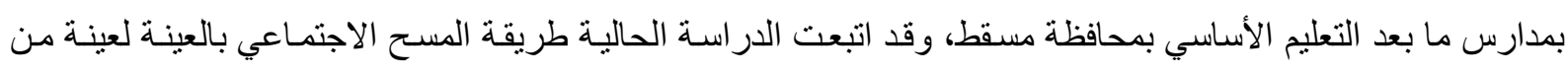



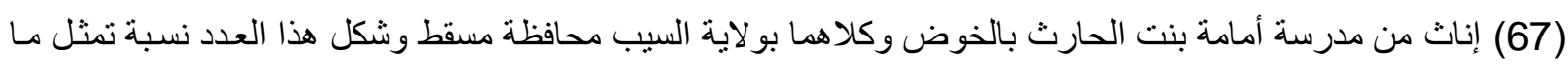

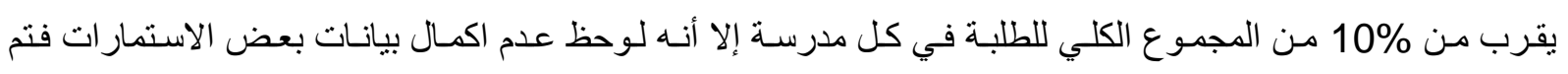
استبعادها وكذللك عدم رغبة بعض طلاب وطالبات الصف الحادي عشر في تعبئة الأداة. كما اعتمدت الدراسة على مقياس للعنف اللفظي الذي هو من تصميم الباحث والذي تكون من قسمين، القسم الأول تضمن عدد (29) عبارة لقياس العنف اللفظي الممارس من قبل ولى الأمر، في حين اختص القسم الثاني و الذي تضمن أيضـا (29) عبارة بقياس العنف اللفظي

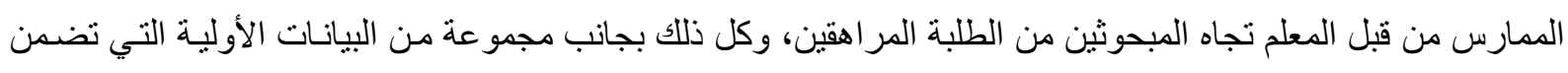
الجانب التعريفي للمبحوثين و الذي اشتمل على متغير ات مستقلة مثل: النوع، و الصف الدر اسي، و المستوى التعليمي لولي

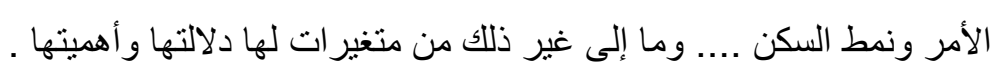
ولقد تم اختبار صدق Validity هذا المقياس بعرضه علي عدد 1 محكمين هم أعضاء هيئة التدريس تخصص على علم

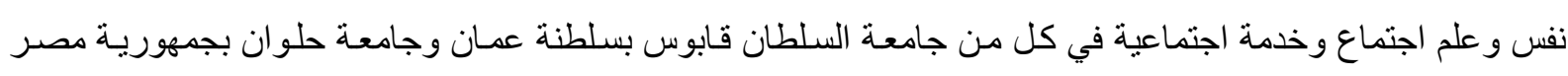


العربية ـ كذلك تم اختبار الاتساق الداخلي للمقياس باستخدام معامل " ألفا كرومباخ " حيث بلغت قيمته (0.947 ) وهو يعد مؤشر ا متميز ا على قياس ثبات الاتساق الداخلي للأداة.

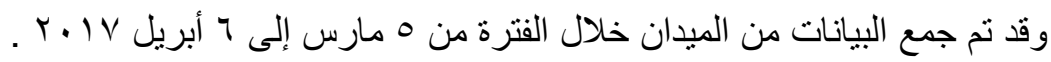
تحليل البيانات الميدانية: 1- ـ وصف مجتمع الدراسـة: تم تطبيق الدر اسـة الحالية على عينـة من الطلبة المر اهقين بالصفوف الحسادي عشر و الثاني عشر بلـغ عددها (145) طالبـا وطالبة، حيث بلغت نسبة الذكور 53.8\% بينمـا بلغت نسبة الانـاث 46.2\% كما بلغت نسبة الطلاب المبحوثين من الصف الحادي عشر 34.5 34.5 ونسبتهم من الصف الثاني عشر 65.5\%، ويفسر الباحث زيادة نسبة المشاركين من الصف الثاني عشر بارتفاع مستوى نضجهم عن نظر ائهم من الصف الحادي عشر ، والجدول رقم (1) يبين التوزيع النوعي و الصفي للطلبة المبحوثين. جدول رقم (1) التوزيع النوعي و الصفي للمر اهقين

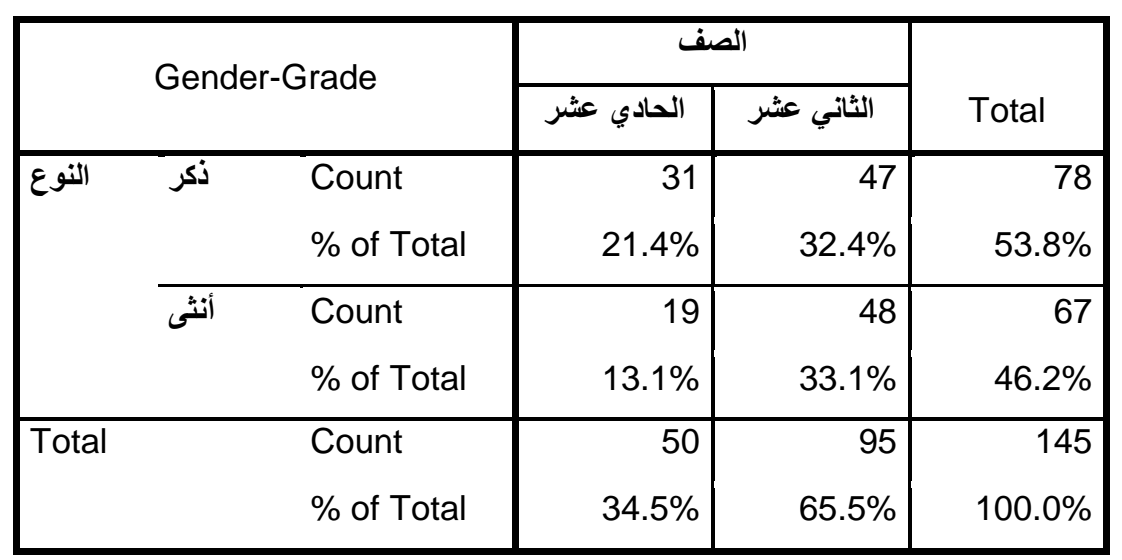

أما عن المستوى التحصيلي للطلبة المراهقين فيمكن استنتاج ذللك من خلال الاطلاع على الثكل البياني رقم (1)، و الذي يفيد بأن غالبيتهم من ذوي المستوى التحصيلي المرتفع حيث بلغت نسبة المتميزين منهم 52.40\%، بينما بغت نسبة ذوي المستوى الجيد 32.40\%، بينما بلغت نسبة الطلبة ذوي المستوى المتوسط بـ 9.70 فقط، ونسبة المستوى الضعيف 50\% 5قط.

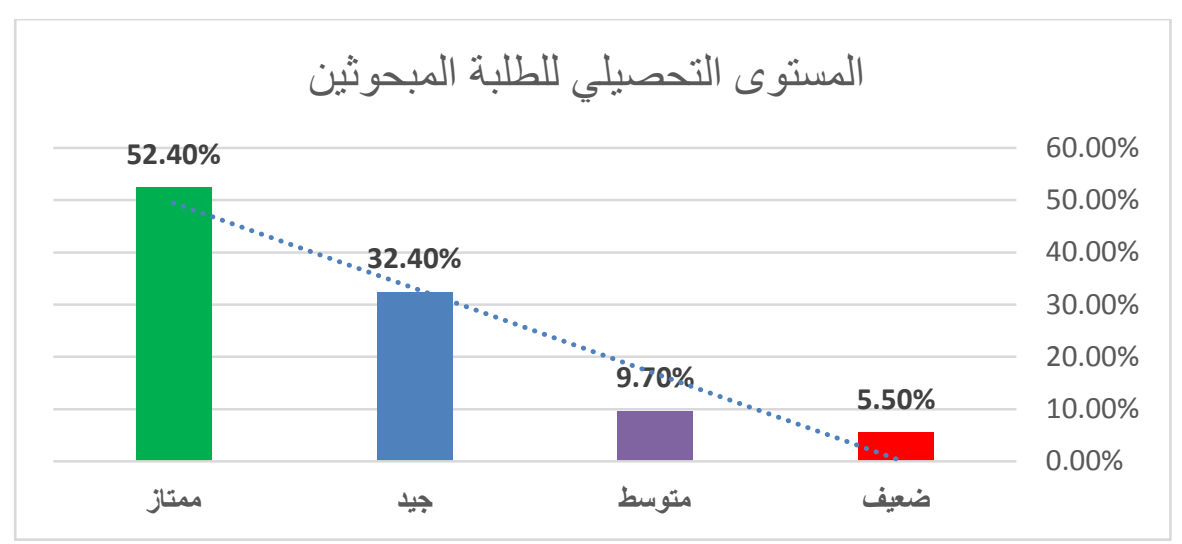

شكل رقم (1) - (1) - (1)

المستوى التحصيلي للطلبة المبحوثين 
كمـا يختص الجدول رقم (2) بتوضيح عدد الأخوة للطلبة المر اهقين الذين تضمنتهم الدر اسـة، حيث اتضـح أن غالبيتهم ينتمون إلى أسر كبيرة الحجم، إذ أفاد 64.8\% منهم بأن لديهم أكثر من 5 أخوة، بينما أفادت النسبة الأقل المقدرة بـ 8.3\% بأن لديهم أقل من 3 أخوة.

جدول رقم (2) (2)

عدد الأخوة للطلبة المراهقين

\begin{tabular}{|c|c|c|c|}
\hline \multicolumn{2}{|c|}{ Number of Brothers- Sisters } & Frequency & Percent \\
\hline \multirow[t]{4}{*}{ Valid } & أقل من 3 أخوة & 12 & 8.3 \\
\hline & من 3 الى 5 أخوة & 39 & 26.9 \\
\hline & أكثر من 5 أخوة & 94 & 64.8 \\
\hline & Total & 145 & 100.0 \\
\hline
\end{tabular}

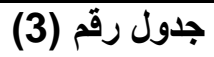

الحالة العملية لولى الأمر

\begin{tabular}{|c|c|c|}
\hline Working Status & Frequency & Percent \\
\hline Valid & 100 & 69.0 \\
\hline لا يعمل & 45 & 31.0 \\
\hline Total & 145 & 100.0 \\
\hline
\end{tabular}

توضح البيانات الواردة بالجدول رقم (3) الحالة العملية لولى الامر، حيث يتضح ان غالبية أولياء الأمور من الذين

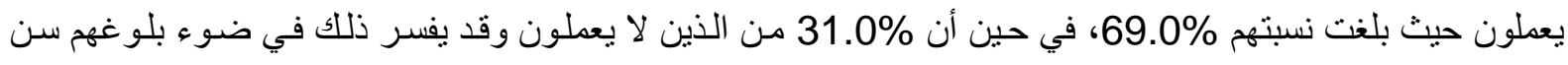
التقاعد أي انهم أكبر من 60 سنة. أما عن المستوى التعليمي لأولياء الأمور فقد أفادت البيانات التي يمثلها الثكل رقم (2) أن غالبية أولياء الأمور من ذوي المستوى التعليمي المرتفع وذلك بنسبة 79.30\% بينما بلغت نسبة الأميين منهم

8.30\%، ولمزيد من التفاصيل يمكن الاطلاع على النكل النالي رقم (2).

$79.30 \%$

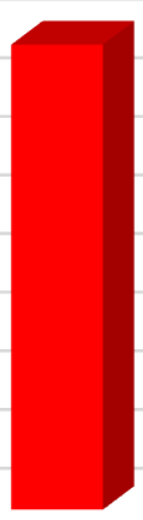

ثانوي فما فوق المستوى التعليمي لأولياء الأمور
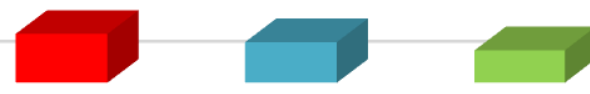

ابتدائي

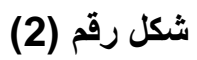

توزيع أولياء الأمور طبقا للمستوى التعليمي.

جدول رقم (4) 
نمط ملكية السكن

\begin{tabular}{|c|c|c|c|}
\hline \multicolumn{2}{|c|}{ Type of House } & Frequency & Percent \\
\hline Valid & ملك & 97 & 66.9 \\
\hline & ايجار & 48 & 33.1 \\
\hline & Total & 145 & 100.0 \\
\hline
\end{tabular}

تفبد البيانات الواردة بالجدول رقم (4) بأن غالبية المبحوثين يقطنون في مساكن مملوكة لأسرهم وذلك بنسبة 66.9\% منهم في حين بلغت نسبة الذين يقطنون في مساكن مستأجرة 33.1\%؛ وقد حاول الباحث من خلال التعرف على نمط ملكية السكن استخدامه كمؤشر لقياس المستوى الاقتصادي لهم؛ ومن ثم يمكن القول أن غالبية المبحوثين ينتمون الى أسر ذات مستوى اقتصادي غير ضعيف على الأقل.

\section{r- الإجابة عن تساؤلات الاراسة واختبار فرضياتها:}

السؤال الأول: ما مستوى العنف اللفظي الذب يتعرض له الطلاب من قبل ولى الأمر (الأبـ الأم)؟ تتعلق الجداول (1-5، 2-5) بتقديم إجابة مفصلة حول مستوى العنف اللفظي الموجه من قبل أولياء الأمور ضد أبنائهم من الطلبة المبحوثين، وقد اعتمد الباحث على استخدام المتوسط الحسابي والانحر اف المعياري لقياس مدى قوة العبار ات ات المستخدمة في قياس العنف اللفظي، كما اعنمد الباحث على استخدام معادلة القوة النسبية (*) لقياس مستوى العنف اللفظي

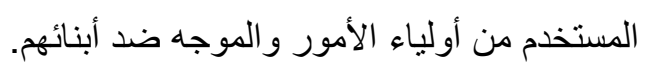

تتضمن البيانات الواردة بالجدول رقم (1-5)، العبار ات ذا المستوى القوى جدا من التأثثر في البعد والتي يبلغ منوسطها الحسابي ( 80\% فأكثر)، أو بمعنى آخر العبار ات التي تعبر عن أنماط العنف اللفظي الأكثر تداولا واستخداما من قبل ولى الأمر والموجهة للأبناء من الطلبة المراهقين وقد تم نرتيب هذه العبارات تنازليا وفق لمستوى تأثيرها

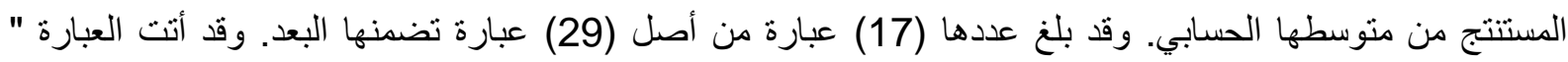
يسخر مني أمام الاخرين. " في الترتيب الأول حيث بلغ مستوى تأثثرها (0.94)، ثم في الترتيب الثاني العبارة " دائماً

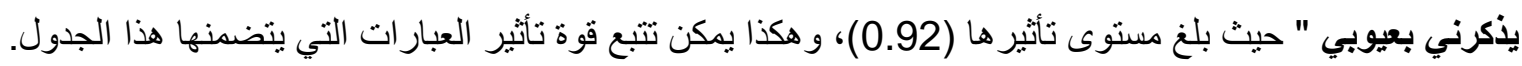

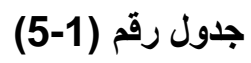

العبارات ذات المستوى القوي جدا من العنف اللفظي المستخدم من قبل ولى الأمر

$\mathrm{N}=145$

\begin{tabular}{|c|c|c|c|}
\hline المستوى & الانحر اف المعياري & المتوسط & 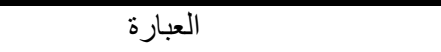 \\
\hline 0.94 & .80724 & 4.7103 & يسخر مني أمام الاخرين. \\
\hline 0.92 & .98027 & 4.6138 & دائماً يذكرني بعيوبي. \\
\hline 0.90 & 1.02824 & 4.5034 & يلومني كثبراً بسبب او بدون سبب. \\
\hline 0.88 & 1.02940 & 4.3931 & دائماً بسمعني عبارة لو لم يكن انجبني. \\
\hline 0.87 & .84718 & 4.3586 & يسمع اصدقائي بعض الكلمات الجارحة. \\
\hline 0.86 & 1.41184 & 4.3103 & يناديني بأسماء الحيو انات. \\
\hline 0.85 & 1.07225 & 4.2552 & يهادني بحجزي في غرفة اذا ما اخطأت. \\
\hline
\end{tabular}

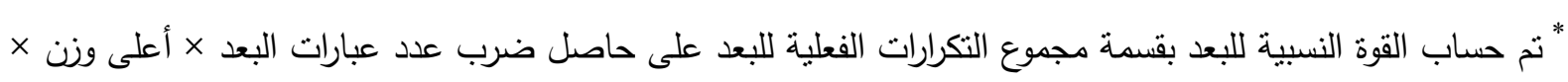

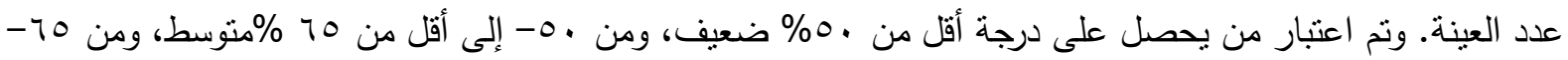

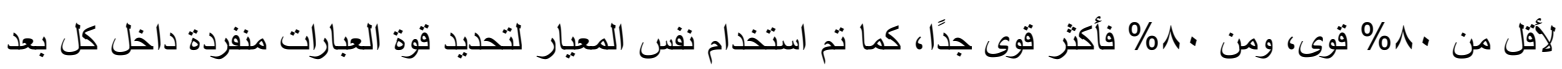




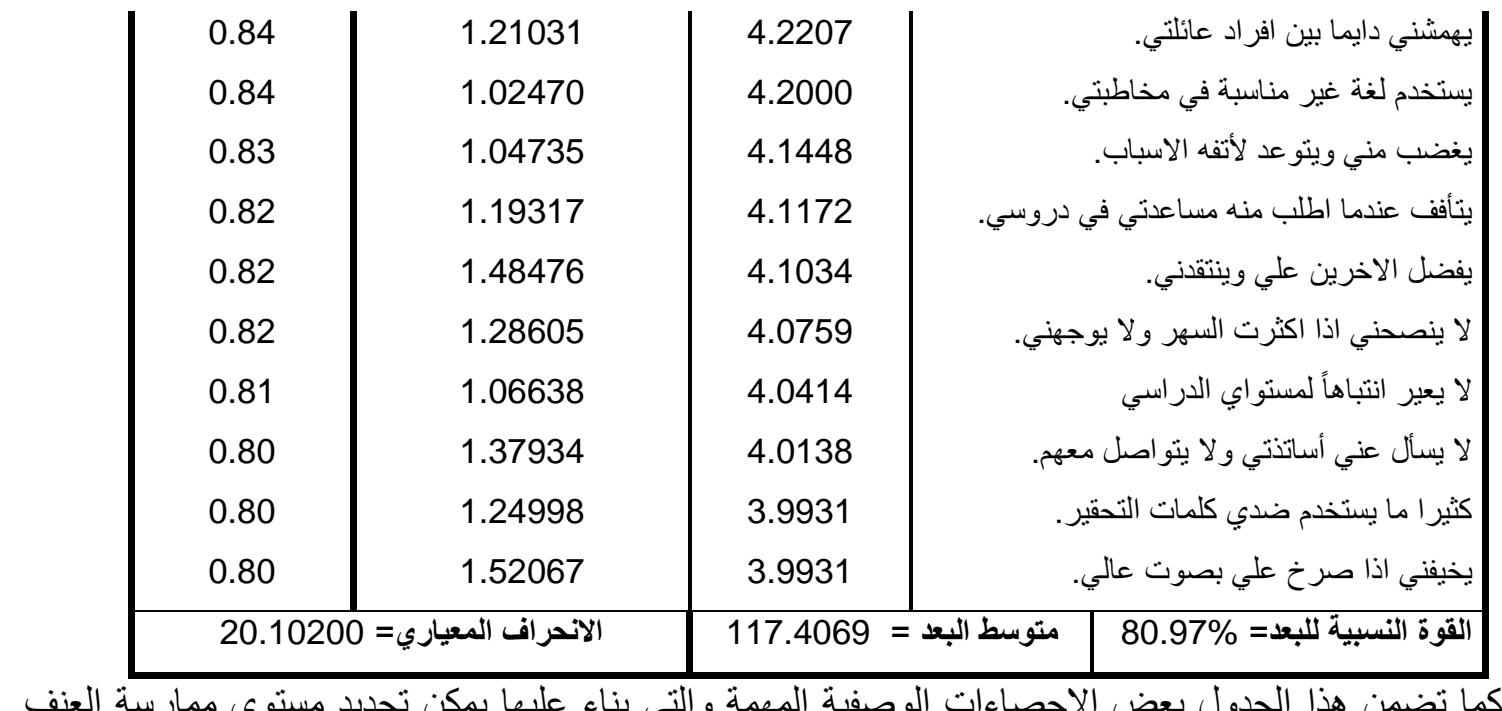

اللفظي من قبل ولي الأمر، حيث بلغت قيمة القوة النسبية للبعد 81.97\% وطبقا للمعيار الذي اعتمده الباحث لتحديد مستوى هذه القوة؛ يمكن الإقرار بأنه مستوى العنف اللفظي الممارس من قبل ولي الأمر قوى جدا. كذلك بلغت قيمة المتوسط الحسابي للبعد (117.4069) وقيمة الانحر اف المعياري للبعد (20.10200). بينما يتضمن جدول رقم (2-5) العبارات ذات المستوى القوي من العنف اللفظي المستخدم من قبل ولى الأمر، حيث تر اوح مستوى تأثثر ها (بين 65\% إلى أقل من 80\%)، وقد أنت العبارة "ينهرني ولا يعطني المجال للتعبير عن وجهة نظري" في الترتيب الأول في هذا المستوى القوى؛ حيث بلغ مستوى تأثير ها (0.79)، تلتها العبارة " لا يشجعني

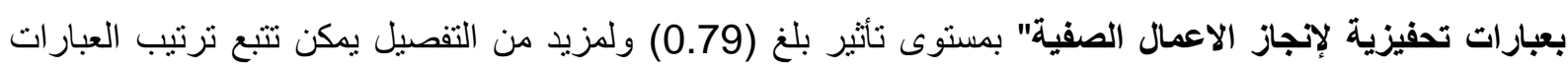
بالجدول وفقا لمستوى تأثثير ها.

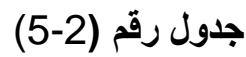
العبارات ذات المستوى القوي من العنف اللفظي المستخدم من قبل ولى الأمر

$\mathrm{N}=145$

\begin{tabular}{|c|c|c|c|}
\hline 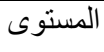 & الانحر اف المعياري & المتوسط & 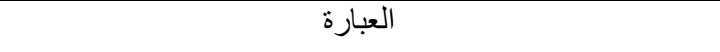 \\
\hline 0.79 & 1.32783 & 3.9724 & ينهرني و لا يعطني المجال للتعبير عن وجهة نظري. \\
\hline 0.79 & 1.35613 & 3.9655 & لا يشجعني بعبارات تحفيزية لإنجاز الاعمال الصفية. \\
\hline 0.78 & 1.45165 & 3.8966 & يمدح اخوتي بطريقة افضل مني. \\
\hline 0.77 & 1.72906 & 3.8690 & دائماً يسمعني عبارة ار هتتني بمصاريفك الدراسية. \\
\hline 0.77 & 1.27464 & 3.8552 & يوبخني بشدة عندما اخطئ . \\
\hline 0.76 & 1.44178 & 3.8207 & لا يمدحني عندما انجز واجباتي. \\
\hline 0.76 & 1.62953 & 3.7862 & كثبراً ما يناديني بعبارات لفظية جارحة. \\
\hline 0.76 & 1.33430 & 3.7862 & 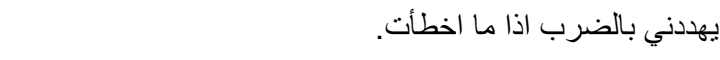 \\
\hline 0.75 & 1.61165 & 3.7655 & دائماً ما يكرر على مسمعي عبار ات انت فانل \\
\hline \multirow[t]{2}{*}{0.73} & 1.70299 & 3.6345 & يناديني بألقاب وبأسماء مضحكة. \\
\hline & 1.62063 & 3.5172 & يحبطني وير هقني بكلمة لا عندما اطلب منه حضور اجتماع اولياء \\
\hline 0.70 & & & الامور. \\
\hline 0.70 & 1.51894 & 3.4897 & يقارنني ببعض التلاميذ. \\
\hline
\end{tabular}

السؤال الثاني: ما مستوى العنف اللفظي الذي يتعرض له الطلاب من قبل المعلم؟ 
تتعلق الجداول (1-6، 2-6) بتقديم إجابة مفصلة حول مستوى العنف اللفظي الموجه من قبل المعلم تجاه الطلبة المبحوثين، وبخلاف النتائج السابقة المتعلقة بالعنف اللفظي الموجه من فبل أولياء الأمور، فقد بلغ عدد العبارات التي

تجسد ممارسات العنف الفظي ذات المستوى القوى جدا (10) عبار ات فقط. وقد تم ترتيب هذه العبارات تنازليا وفقا لمستوى تأثثرها، فأتت العبارة " يقارنني ببعض التلاميذ " في الترتيب الأول بمستوى تأثثر بلغت قوته (0.88)، وفى الترتيب الثاني أتت العبارة " يناديني بألقاب وبأسماء مضحكة " بمستوى

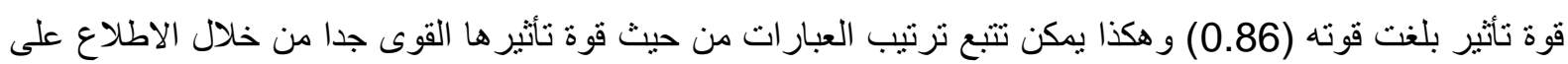
الجدول الناحق.

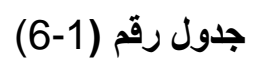

العبارات ذات المستوى القوي جدا من العنف اللفظي المستخدم من قبل المعلم

$N=145$

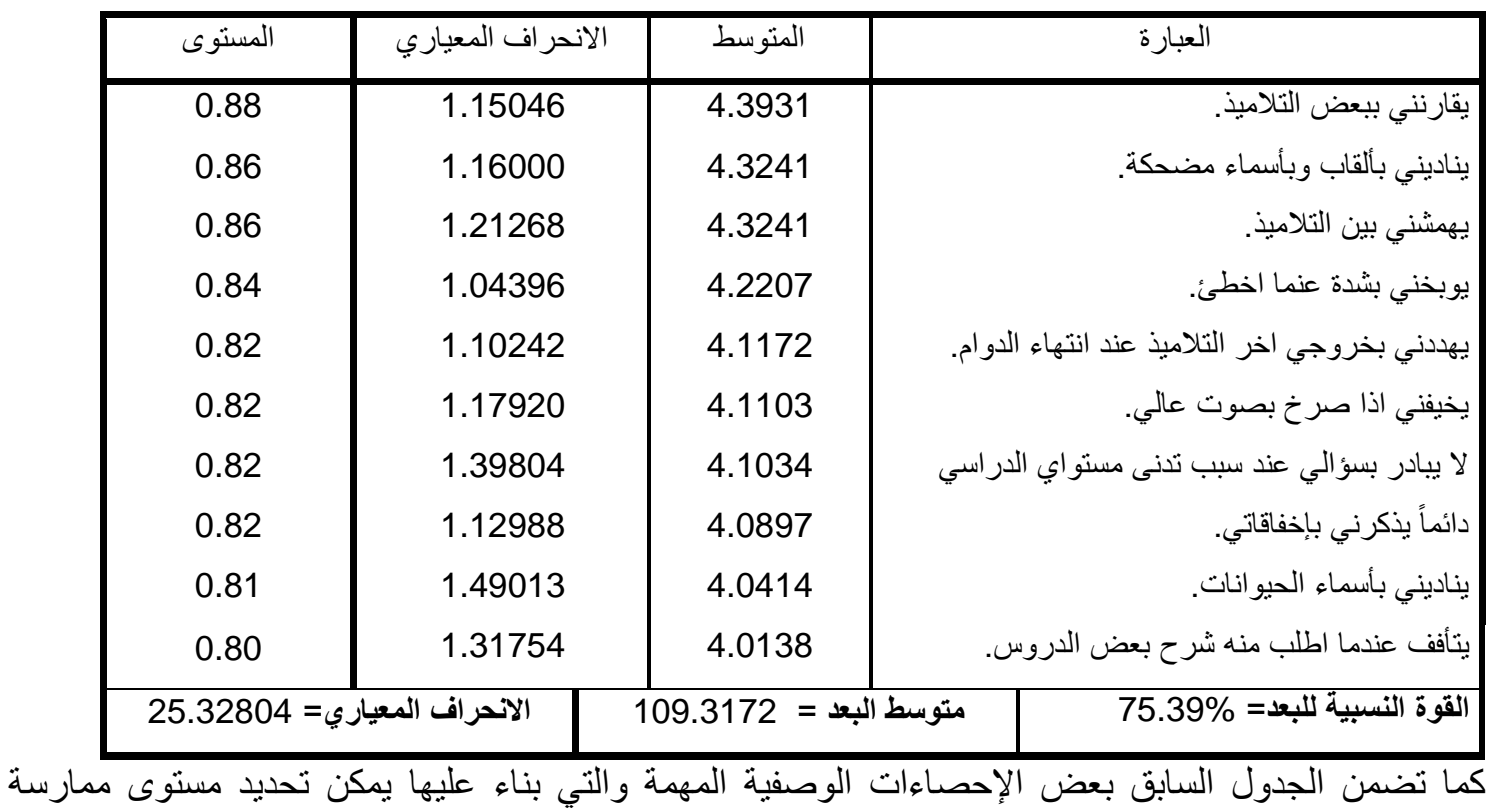

العنف اللفظي من قبل المعلم تجاه الطلبة المراهقين بشكل عام، حيث بلغت قيمة القوة النسبية للبعد 75.39\% وطبقاء للمعيار الذي اعتمده الباحث لتحديد مستوى هذه القوة؛ يمكن الإقرار بأنه مستوى العنف اللفظي الممارس من قبل |لمعلم مستوى قوى فقط و هذا بخلاف مستوى العنف اللفظي الممارس من قبل ولى الأمر و الذي وصف بالقوى جدا. كذلك بلغت قيمة المتوسط الحسابي لهذا البعد (109.3172) وقيمة انحر افه المعياري (25.32804). بينما تضمن جدول رقم (2-6) العبار ات ذات المستوى القوي و المستوى المنوسط من العنف اللفظي المستخدم من قبل المعلم تجاه الطلبة المراهقين، حيث جسدت (16) عبارة ممارسات العنف اللفظي ذات التأثثر القوى إذا نراوحت قوة تأثير ها بين ( 65\% إلى أقل من 80\%)، بينما مثلت (3) عبارات فقط ممارسات العنف اللفظي ذات التأثير المتوسط من قبل المعلم.

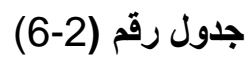

العبارات ذات المستوى القوي والمتوسط من العنف اللفظي المستخدم من قبل المعلم

$\mathrm{N}=145$

\begin{tabular}{|c|c|c|c|}
\hline \multicolumn{4}{|c|}{ العبارات الدالة على ممارسة العنف اللفظي وتوصف بذات التأثير القوى } \\
\hline المستوى & الانحر اف المعياري & المتوسط & العبارة \\
\hline
\end{tabular}




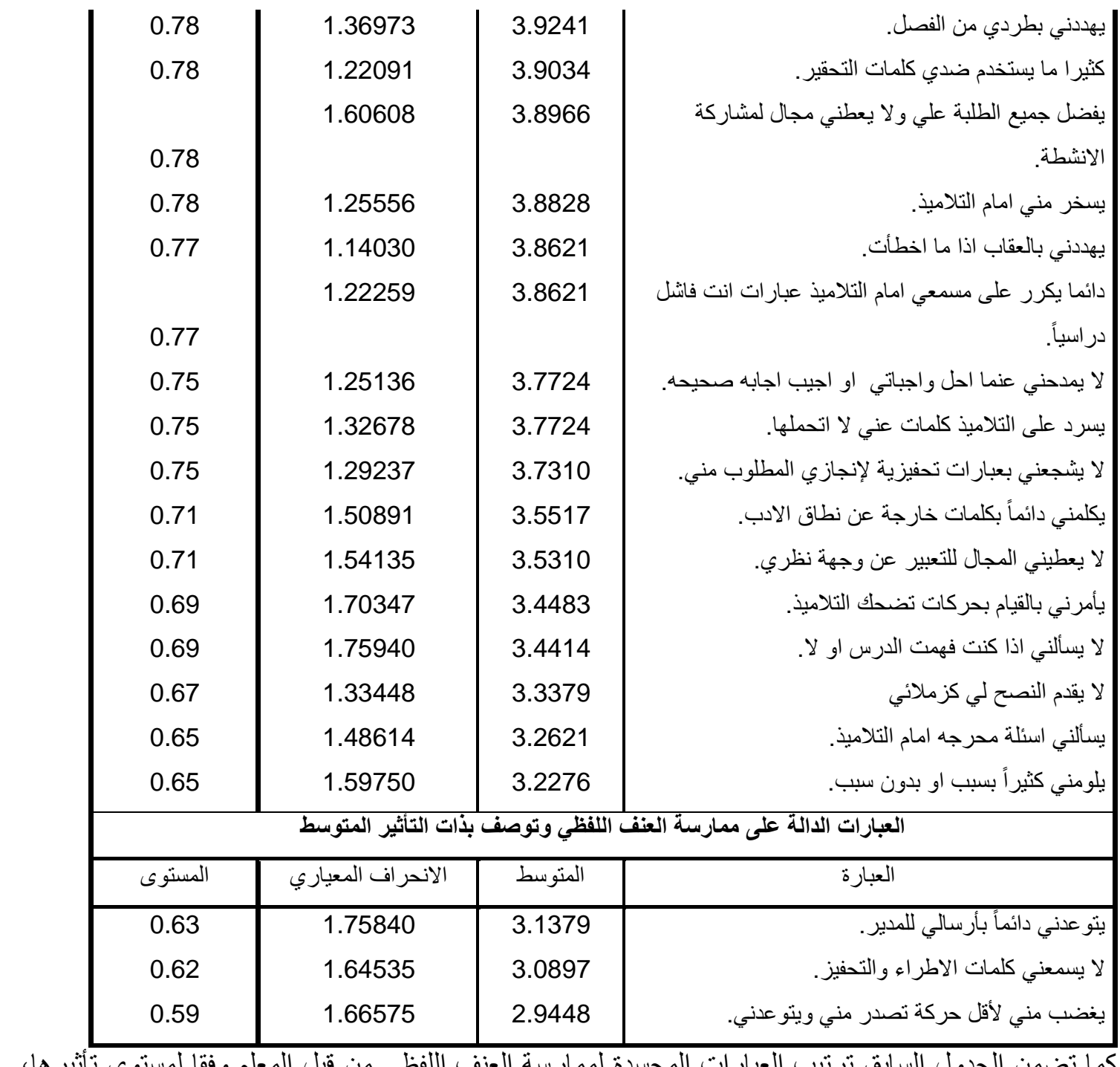

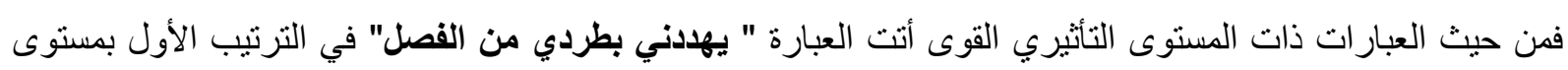

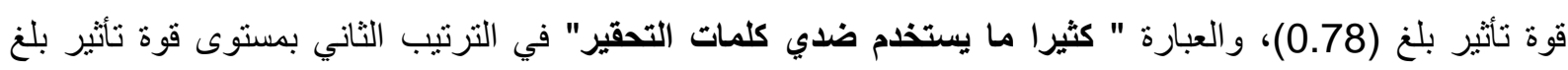
(0.78)، و هكذا يمكن تتبع مستوى قوة تأثير العبار ات ذات المستوى القوى وفقا لترتيبها بالجدول. أيضا تضمن الجدول رقم (2-6) عبارات فقط تجسد التأثير المنوسط لممارسات العنف اللفظي من قبل المعلم تجاه

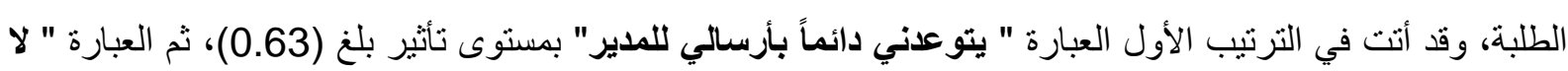

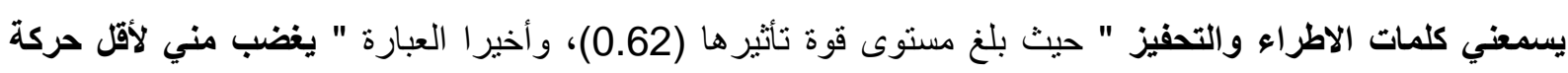
تصدر مني ويتوعدني" في الترتيب الأخير حيث بلغ مستوى قوة تأثير ها (0.59).

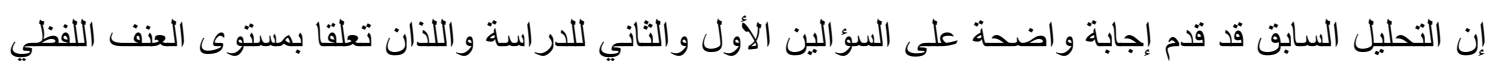
الممارس من قبل ولى المر و المعلم تجاه الأبناء والطلبة المر اهقين، حيث اتضح أن مستوى العنف اللفظي الممارس من الإن ولن

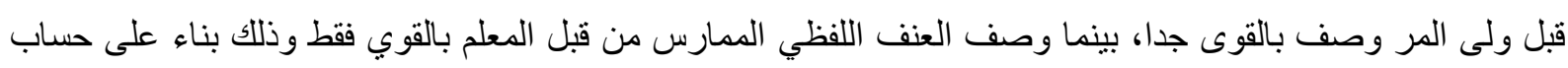

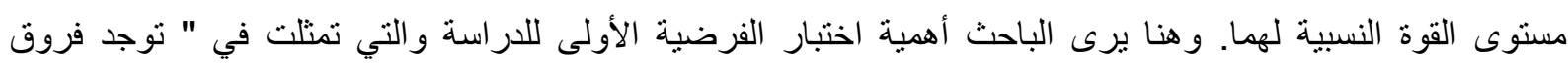
احصائية ذات دلالة معنوية بيين العنف اللفظي الممارس من قبل ولى الأمر والعنف الممارس من قبل المعلم تجاه طلبة الصفوف (12-11). و لاختبار هذه الفرضية نم تطبيق اختبار (Paired Samples Test) وجود فروق إحصائية ذات دلالة معنوية لصالح أولياء الأمور (المتوسط الحسابي الأكبر) والجدول التالي يوضح نتيجة 
تطبيق هذا الاختبار ؛ حيث بلغت قيمة الــ P-Value أقل من 0.05 و هذا يؤكد على وجود الفروق وقد فسرت الفروق

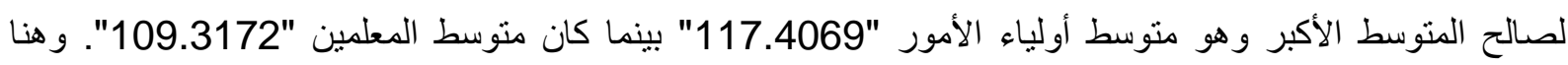
يوصى اباحث بأهمية التعامل مع كل من أولياء الأمور و المعلمين لمساعدتهم على خفض مستوى ممارسات العنف اللفظي المرتفع تجاه المر اهقين من الطلاب الذين طبقت عليهم الدراسة.

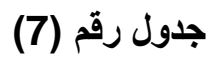

الفروق الإحصائية بين العنف اللفظي المستخدم من أولياء الأمور والمعلمين تجاه الطلبة

Paired Samples Test

\begin{tabular}{|c|c|c|c|c|c|c|c|c|}
\hline & \multicolumn{5}{|c|}{ Paired Differences } & \multirow[b]{3}{*}{$\mathrm{t}$} & \multirow[b]{3}{*}{ df } & \multirow{3}{*}{$\begin{array}{l}\text { Sig. } \\
(2- \\
\text { tailed })\end{array}$} \\
\hline & \multirow[b]{2}{*}{ Mean } & \multirow{2}{*}{$\begin{array}{c}\text { Std. } \\
\text { Deviatio } \\
\mathrm{n}\end{array}$} & \multirow{2}{*}{$\begin{array}{l}\text { Std. } \\
\text { Error } \\
\text { Mean }\end{array}$} & \multicolumn{2}{|c|}{$\begin{array}{c}95 \% \text { Confidence } \\
\text { Interval of the } \\
\text { Difference }\end{array}$} & & & \\
\hline & & & & Lower & Upper & & & \\
\hline  & $\begin{array}{r}8.0896 \\
6\end{array}$ & $\begin{array}{r}23.6402 \\
2\end{array}$ & $\begin{array}{r}1.9632 \\
1\end{array}$ & $\begin{array}{r}4.2092 \\
2\end{array}$ & 11.97009 & 4.121 & 144 & .000 \\
\hline
\end{tabular}

كما قام الباحث باختبار الفرضيات الخاصة بالتعرف على مدى وجود فروق في ممارسة العنف اللفظي طبقا

للنوع، وطبقا للفصل الدراسي"، فأما الفرضية المتعلقة بالنوع والتي تمثلت في " توجد فروق احصائية ذات دلالة معنوية بين منوسطات درجات الطلبة على مقياس العنف اللفظي الموجه من ولي الأمر طبقا لمتغير النوع"، فقد أكدت نتائج تطبيق اختبار و المعلمين تجاه المر اهقين من الطلبة طبقا للنوع في محور ولي الأمر ومحور المعلم وفى المقياس ككل ؛ حيث كانت قيم

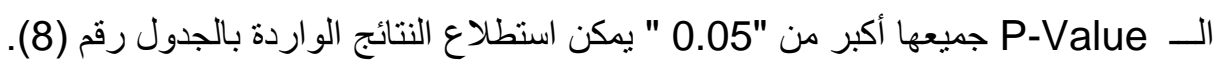

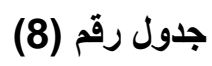

الفروق الإحصائية بين العنف اللفظي المستخدم من أولياء الأمور والمعلمين طبقا للنوع

Independent Samples Test

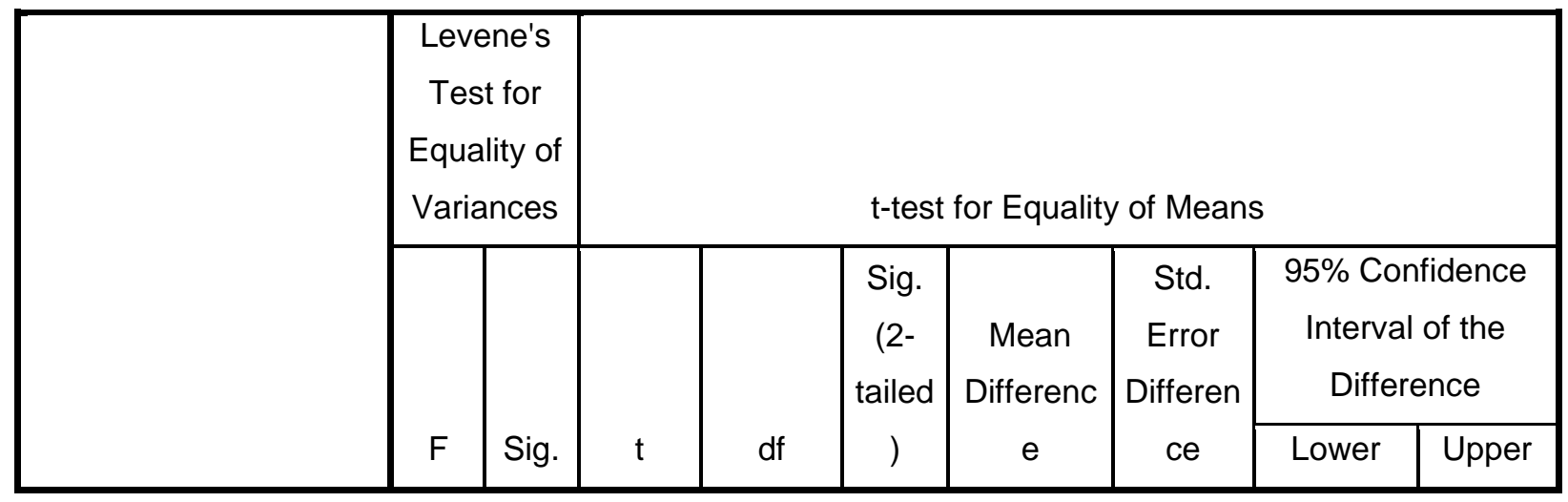




\begin{tabular}{|c|c|c|c|c|c|c|c|c|c|c|}
\hline اللفظي & $\begin{array}{l}\text { Equal } \\
\text { variances } \\
\text { assumed } \\
\text { Equal } \\
\text { variances not } \\
\text { assumed }\end{array}$ & .618 & .433 & $\begin{array}{r}1.394- \\
- \\
1.388-\end{array}$ & $\begin{array}{r}136.98 \\
1\end{array}$ & .165 & $\begin{array}{r}\text { 4.65404- } \\
\text { 4.65404- }\end{array}$ & $\begin{array}{r}3.3374 \\
8 \\
\\
3.3519 \\
9\end{array}$ & $\begin{array}{r}11.25121 \\
11.28237\end{array}$ & $\begin{array}{r}1.9431 \\
3\end{array}$ \\
\hline اللفظي & $\begin{array}{l}\text { Equal } \\
\text { variances } \\
\text { assumed } \\
\text { Equal } \\
\text { variances not } \\
\text { assumed }\end{array}$ & .525 & .470 & .093 & $\begin{array}{r}138.45 \\
8\end{array}$ & .926 & $\begin{array}{l}.39552 \\
.39552\end{array}$ & $\begin{array}{r}4.2335 \\
1 \\
4.2425 \\
8\end{array}$ & $\begin{array}{l}-7.97283 \\
-7.99311\end{array}$ & $\begin{array}{r}8.7638 \\
7 \\
\\
8.7841 \\
5\end{array}$ \\
\hline ككل المقياس & $\begin{array}{l}\text { Equal } \\
\text { variances } \\
\text { assumed } \\
\text { Equal } \\
\text { variances not } \\
\text { assumed }\end{array}$ & .712 & .400 & $-.647-$ & $\begin{array}{r}135.23 \\
5\end{array}$ & .516 & $\begin{array}{r}- \\
4.25852- \\
4.25852-\end{array}$ & $\begin{array}{r}6.5335 \\
0 \\
\\
6.5771 \\
7\end{array}$ & $\begin{array}{r}- \\
17.17323 \\
- \\
17.26592\end{array}$ & $\begin{array}{r}8.6562 \\
0 \\
\\
8.7488 \\
9\end{array}$ \\
\hline
\end{tabular}

أما الفرضية الخاصة بالفروق الإحصائية طبقا للصف الدر اسي، و التي تمثلت في "توجد فروق احصائية ذات دلالة

معنوية بين متوسطات درجات الطلبة على مقياس العنف اللفظي الموجه من المعلم طبقا لمتغير الصف الدراسي"، فقد أكدت نتائج نطبيق اختبار T-Test للعينات المستقلة وجود فروق إحصائية ذات دلالة معنوية في مستويات العنف

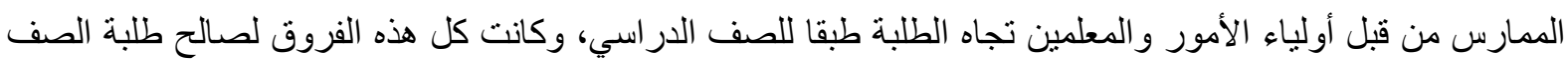
الثاني عشر حيث كانت درجات المنوسط الأكبر من نصييهم في محور ولي الأمر ومحور المعلم وفى المقياس ككل؛ حيث كانت حيث كانت قيم الــ P-Value جميعها أقل من "0.05 " يمكن اسنطلاع النتائج الواردة بالجدول رقم (9). جدول رقم (9) الفروق الإحصائية بين العنف اللفظي المستخدم من أولياء الأمور والمعلمين طبقا للصف الدراسي

Independent Samples Test

\begin{tabular}{|c|c|c|c|c|c|c|c|c|c|}
\hline & \multicolumn{2}{|c|}{\begin{tabular}{|c|} 
Levene's \\
Test for \\
Equality of \\
Variances
\end{tabular}} & \multicolumn{7}{|c|}{$\mathrm{t}$-test for Equality of Means } \\
\hline & \multirow[b]{2}{*}{$\mathrm{F}$} & \multirow[b]{2}{*}{ Sig. } & \multirow[b]{2}{*}{$\mathrm{t}$} & \multirow[b]{2}{*}{ df } & \multirow{2}{*}{$\begin{array}{l}\text { Sig. } \\
(2- \\
\text { taile } \\
\text { d) }\end{array}$} & \multirow{2}{*}{$\begin{array}{c}\text { Mean } \\
\text { Difference }\end{array}$} & \multirow{2}{*}{$\begin{array}{l}\text { Std. } \\
\text { Error } \\
\text { Differe } \\
\text { nce }\end{array}$} & \multicolumn{2}{|c|}{$\begin{array}{l}\text { 95\% Confidence } \\
\text { Interval of the } \\
\text { Difference }\end{array}$} \\
\hline & & & & & & & & Lower & Upper \\
\hline $\begin{array}{ll}\text { Equal variances } \\
\text { اللفظي } \\
\text { من ولى Equal variances } \\
\text { اللفئ not assumed }\end{array}$ & 82.50 & .000 & $\begin{array}{r}11.815- \\
- \\
16.312-\end{array}$ & $\begin{array}{r}143 \\
94.00\end{array}$ & .000 & $\begin{array}{r}29.62105- \\
\text { - } \\
29.62105-\end{array}$ & $\begin{array}{r}2.5071 \\
8 \\
1.8158 \\
9\end{array}$ & $\begin{array}{r}34.57697- \\
- \\
33.22655-\end{array}$ & $\begin{array}{r}24.66514- \\
\text { 26.01556- }\end{array}$ \\
\hline
\end{tabular}




\begin{tabular}{|c|c|c|c|c|c|c|c|c|c|c|}
\hline اللفظي & $\begin{array}{l}\text { Equal variances } \\
\text { assumed } \\
\text { Equal variances } \\
\text { not assumed }\end{array}$ & 96.23 & .000 & $-5.445-$ & 96.63 & .000 & $\begin{array}{r}22.00526- \\
- \\
22.00526-\end{array}$ & $\begin{array}{r}4.0414 \\
9 \\
2.9420 \\
2\end{array}$ & $\begin{array}{r}29.99404- \\
- \\
27.84465-\end{array}$ & $\begin{array}{r}14.01648- \\
- \\
16.16588\end{array}$ \\
\hline ككل المقياس & $\begin{array}{l}\text { Equal variances } \\
\text { assumed } \\
\text { Equal variances } \\
\text { not assumed }\end{array}$ & 143.0 & .000 & - & 95.51 & .000 & $\begin{array}{r}51.62632- \\
- \\
51.62632-\end{array}$ & $\begin{array}{r}5.3353 \\
1 \\
3.8755 \\
1\end{array}$ & $\begin{array}{r}62.17258- \\
- \\
59.31965-\end{array}$ & $\begin{array}{r}41.08005- \\
43.93298-\end{array}$ \\
\hline
\end{tabular}

كما تم استخدام معامل التباين الأحادي ANOVA لاختبار الفرضية القائلة " توجد فروق احصائية ذات دلالة

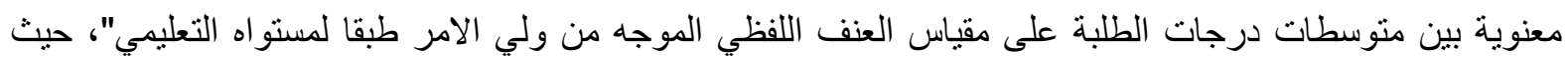
تبين وجود فروق إحصائية ذات دلالة معنوية أحدثها الفارق في المستوى التعليمي ولى الأمر؛ حيث كانت قيمة الــــ Value أقل من "0.05"، و هذا ما توضحه النتائج التي يتضدنها الجدول رقم (10). جدول رقم (10) (10)

الفروق في ممارسة العنف اللفظي من ولي الأمر طبقا لمستواه التعليمي

\begin{tabular}{|l|r|r|r|r|r|}
\hline & Sum of Squares & \multicolumn{1}{|c|}{ df } & Mean Square & F & \multicolumn{1}{l|}{ Sig. } \\
\hline Between Groups & 5842.405 & 3 & 1947.468 & 5.246 & .002 \\
Within Groups & 52346.588 & 141 & 371.252 & & \\
Total & 58188.993 & 144 & & & \\
\hline
\end{tabular}

وللتعرف على هذه الفروق تم استخدام اختبار LSD كأحد اختبار ات " Post Hoc Tests" حيث تبين أنه كلما

قل المستوى التعليمي لولي الأمر كلما ارتفعت ممارسة العنف اللفظي الممارس من قبله تجاه الطلبة المر اهقين، إذ تبين النتائج الواردة بالجدول رقم (11) أن الفروق تكون معنوية في ممارسة العنف من الأميين وذوي التعليم الابتدائي والاعدادي أكثر من ذوي التعليم الثانوي فما فوق، أي انه كلما ارتفع المستوى التعليمي لولى الأمر كلما انخفضت ممارسات العنف اللفظي الممارس منه تجاه المر اهقين من أبنائه الطلية. جدول رقم (11)

اتجاه الفروق في ممارسة العنف اللفظي من ولي الأمر طبقا لمستواه التطليمي

\begin{tabular}{|c|c|c|c|c|c|c|}
\hline \multirow[t]{2}{*}{$\begin{array}{c}\text { التعليمي لولى الأمر }(\mathrm{l}) \\
\text { المستوى }\end{array}$} & \multirow[t]{2}{*}{ لولى الأمستى التعليمي } & \multirow{2}{*}{$\begin{array}{c}\text { Mean } \\
\text { Difference } \\
(\mathrm{I}-\mathrm{J})\end{array}$} & \multirow[b]{2}{*}{ Std. Error } & \multirow[b]{2}{*}{ Sig. } & \multicolumn{2}{|c|}{$\begin{array}{l}\text { 95\% Confidence } \\
\text { Interval }\end{array}$} \\
\hline & & & & & $\begin{array}{l}\text { Lower } \\
\text { Bound }\end{array}$ & $\begin{array}{l}\text { Upper } \\
\text { Bound }\end{array}$ \\
\hline \multirow[t]{3}{*}{ لا يقراو لا } & ابتدائي & .83333 & 8.79456 & .925 & 16.5529- & $\begin{array}{r}18.219 \\
6\end{array}$ \\
\hline & اعدادي & 2.43333 & 8.25003 & .768 & 13.8764- & $\begin{array}{r}18.743 \\
1\end{array}$ \\
\hline & ثانوي فما فوق & $16.65942^{x}$ & 5.84517 & .005 & 5.1039 & 28.214 \\
\hline \multirow[t]{2}{*}{ ابتدائي } & لا يقراولا & $-83333-$ & 8.79456 & .925 & - & 16.552 \\
\hline & يكتب & & & & 18.2196- & 9 \\
\hline
\end{tabular}




\begin{tabular}{|c|c|c|c|c|c|c|}
\hline & ثانوي فما فوق اعدادي & $\begin{array}{r}1.60000 \\
15.82609^{*}\end{array}$ & $\begin{array}{l}9.13957 \\
7.04520\end{array}$ & $\begin{array}{l}.861 \\
.026\end{array}$ & $\begin{array}{r}- \\
16.4683- \\
1.8982\end{array}$ & $\begin{array}{r}19.668 \\
3 \\
29.754 \\
0\end{array}$ \\
\hline اعدادي & لا يقرا ولا & $\begin{array}{c}-2.43333- \\
-1.60000 \\
14.22609\end{array}$ & $\begin{array}{l}8.25003 \\
9.13957 \\
6.35244\end{array}$ & $\begin{array}{l}.768 \\
.861 \\
.027\end{array}$ & $\begin{array}{r}- \\
18.7431- \\
19.6683- \\
1.6677\end{array}$ & $\begin{array}{r}13.876 \\
4 \\
16.468 \\
3 \\
26.784\end{array}$ \\
\hline ثانوي فما فوق & لا لايكتر لائل & $\begin{array}{r}16.65942-{ }^{*} \\
- \\
15.82609-{ }^{*} \\
- \\
14.22609-{ }^{*}\end{array}$ & $\begin{array}{l}5.84517 \\
7.04520 \\
6.35244\end{array}$ & $\begin{array}{l}.005 \\
.026 \\
.027\end{array}$ & $\begin{array}{r}- \\
28.2149- \\
29.7540- \\
- \\
26.7844-\end{array}$ & $\begin{array}{r}5.1039- \\
- \\
1.8982- \\
- \\
1.6677-\end{array}$ \\
\hline
\end{tabular}

${ }^{\star}$. The mean difference is significant at the 0.05 level.

أما عن الفروق التي تحدثها الحالة العملية لولي الأمر في ممارسة العنف اللفظي تجاه المراهقين من الأبناء الطلبة عينة الدراسة، فقد نم اختبار صحة الفرضية القائلة " توجد فروق احصائية ذات دلالة معنوية بين منوسطات درجات الطلبة على مقياس العنف اللفظي الموجه من ولي الامر طبقا لحالته العملية"، وقد تم استخدام اختبار T-Test للعينات المستقلة وقد أكدت نتائج الاختبار وجود فروق إحصائية ذات دلالة معنوية حيث كانت قيمة الـ P-Value أقل "001. " وكانت هذه الفروق في صالح أولياء الأمور الذين يعملون (المتوسط = 121.0816)، أي ان أولياء الأمور الذين يعملون أكثر ممارسة للعنف عن الذين لا يعملون (المتوسط = 109.2444)؛ وقد يفسر ذلك بضغوط العمل التي يتعرضون لها وتعاظم حجم المسؤوليات الملقى على عاتقهم نتيجة لذلك. و الجدول التالي رقم (12) يوضح ذللك.

جدول رقم (12)

\section{الفروق في ممارسة العنف اللفظي لولي الأمر طبقا للحالة العملية}

Independent Samples Test

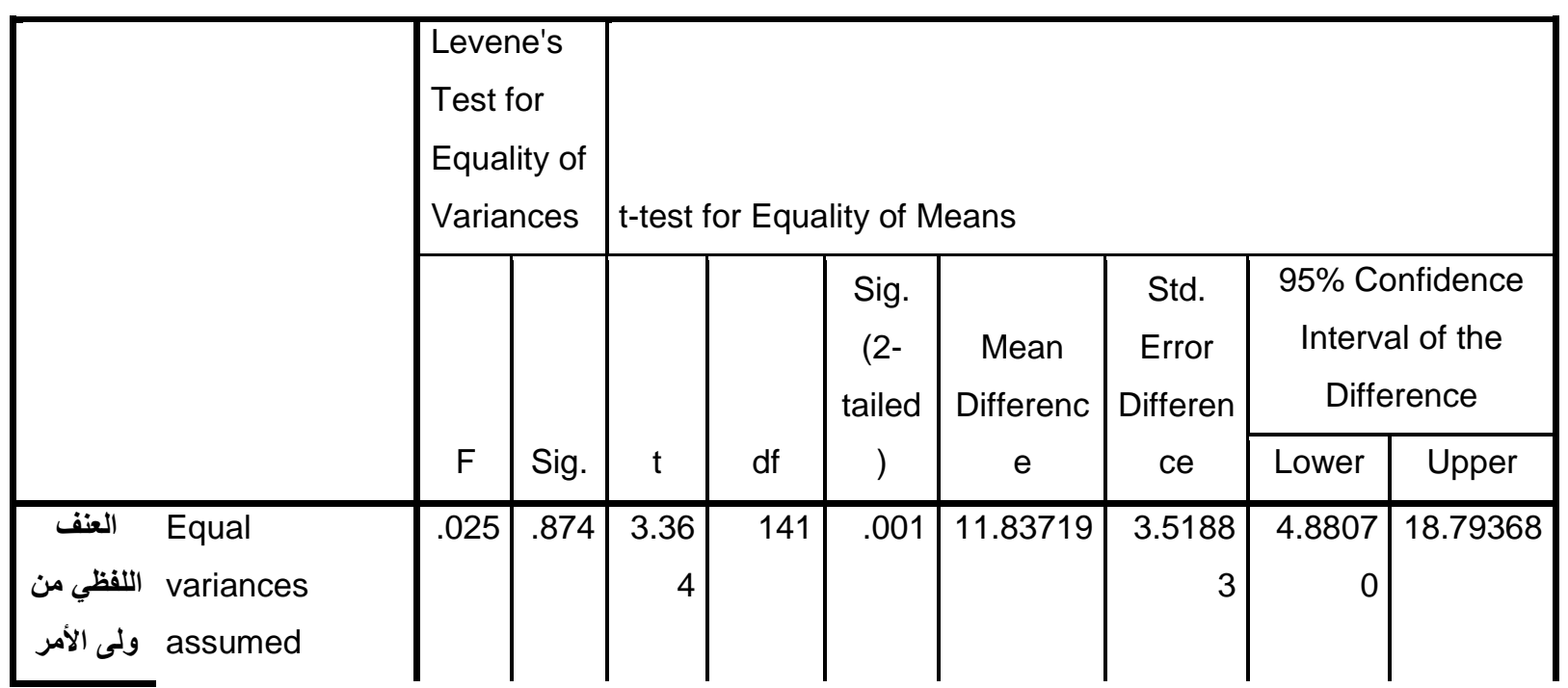




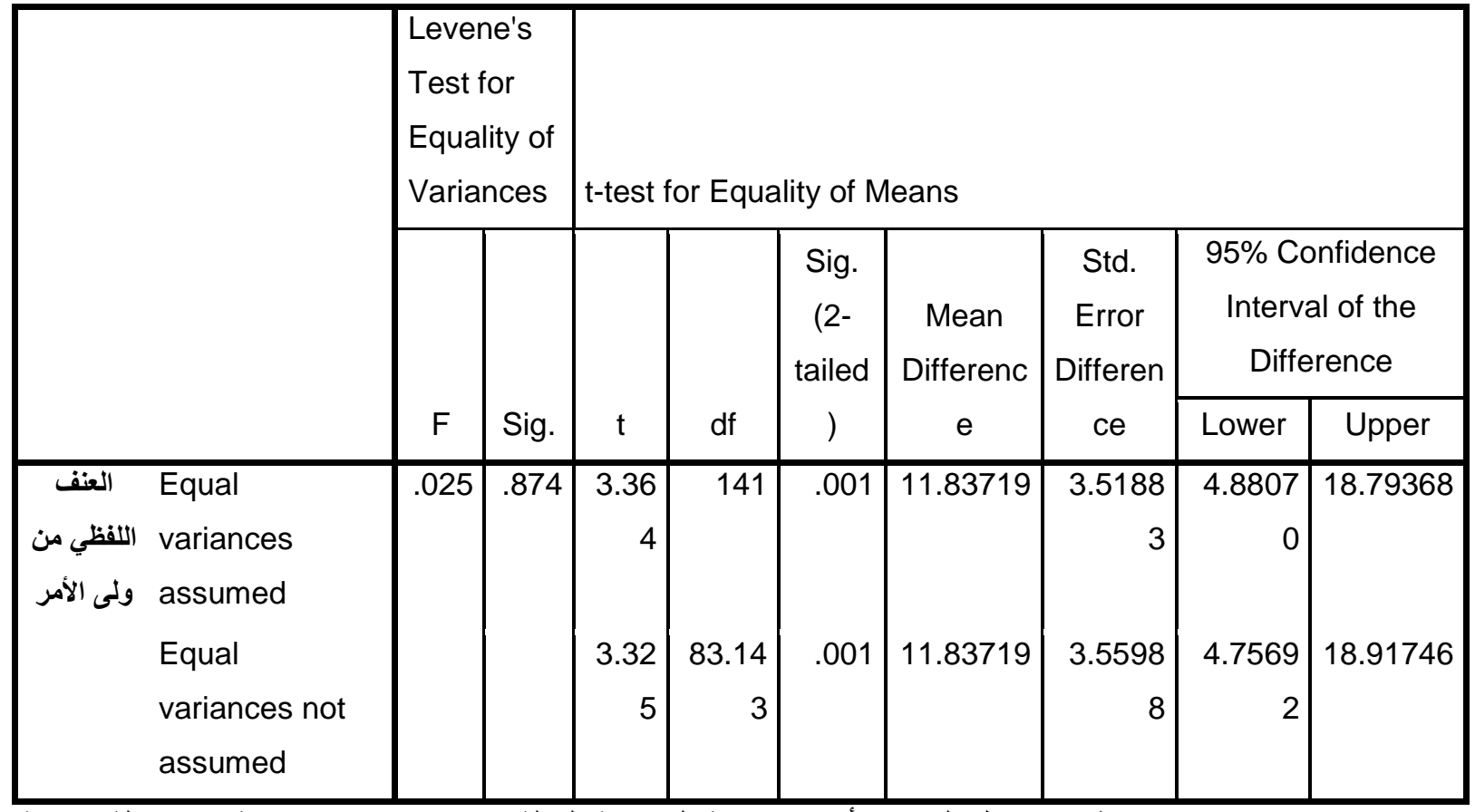

كما بينت نتائج تطبيق معامل التباين الأحادي صحة الفرضية القائلة " توجد فروق احصائية ذات دلالة معنوية بين منوسطات درجات الطلبة على مقياس العنف اللفظي الموجه من المعلم طبقا للمستوى التحصيلي للتلميذ" حيث كانت قيمة الـ P-Value أقل من "0.05". و هذا ما يمكن استتناجه من الجدول التالي رقم (13)

جدول رقم (13)

الفروق في العنف اللفظي من المعلم تجاه الطلبة طبقا لمستو اهم التحصيلي جدادي

\begin{tabular}{|l|r|r|r|r|r|}
\hline & Sum of Squares & \multicolumn{1}{|c|}{ df } & Mean Square & F & \multicolumn{1}{c|}{ Sig. } \\
\hline Between Groups & 11201.015 & 3 & 3733.672 & 6.485 & .000 \\
Within Groups & 81176.392 & 141 & 575.719 & & \\
Total & 92377.407 & 144 & & & \\
\hline
\end{tabular}

وللتعرف على هذه الفروق تم استخدام اختبار LSD كأحد اختبار ات " Post Hoc Tests" حيث تبين أنه كلما

قل قل المستوى التحصيلي للطالب كلما زاد استخدام العنف اللفظي من قبل المعلم تجاهه، حيث يرتفع مسنوى استخدام المعلم للعنف الفظي تجاه الطالب ذي المستوى التحصيلي الضعيف و المتوسط بينما بقل تجاه الطالب ذي المستوى الجيد و الممتاز . و هذا ما توضحه النتائج الواردة بالجدول رقم (14).

جدول رقم (14) (14)

اتجاه الفروق في العنف اللفظي من المعلم تجاه الطلبة طبقا لمستواهم التحصيلي

\begin{tabular}{|c|c|c|c|c|c|c|}
\hline \multirow[t]{2}{*}{ الداسي للطالب التحصيل } & \multirow{2}{*}{ التحصيل الدراسي) } & \multirow{2}{*}{$\begin{array}{c}\text { Mean } \\
\text { Difference } \\
(\mathrm{I}-\mathrm{J})\end{array}$} & \multirow[b]{2}{*}{$\begin{array}{l}\text { Std. } \\
\text { Error }\end{array}$} & \multirow[b]{2}{*}{ Sig. } & \multicolumn{2}{|c|}{$\begin{array}{c}\text { 95\% Confidence } \\
\text { Interval }\end{array}$} \\
\hline & & & & & $\begin{array}{l}\text { Lower } \\
\text { Bound }\end{array}$ & $\begin{array}{l}\text { Upper } \\
\text { Bound }\end{array}$ \\
\hline ضعي & متوسط & 23.14286 & $\begin{array}{r}10.6342 \\
7\end{array}$ & .031 & 2.1196 & $\begin{array}{r}44.166 \\
1\end{array}$ \\
\hline
\end{tabular}




\begin{tabular}{|c|c|c|c|c|c|c|}
\hline & ميد & $\begin{array}{r}1.82979 \\
18.80263^{\star}\end{array}$ & $\begin{array}{l}9.17683 \\
8.91853\end{array}$ & $\begin{array}{l}.842 \\
.037\end{array}$ & $\begin{array}{r}- \\
16.3122- \\
1.1713\end{array}$ & $\begin{array}{r}19.971 \\
8 \\
36.433 \\
9\end{array}$ \\
\hline متوسط & ضعيف & $\begin{array}{r}-23.14286- \\
-21.31307- \\
-4.34023-\end{array}$ & $\begin{array}{r}10.6342 \\
7 \\
7.30562 \\
6.97840\end{array}$ & $\begin{array}{l}.031 \\
.004 \\
.535\end{array}$ & $\begin{array}{r}- \\
44.1661- \\
- \\
35.7558- \\
- \\
18.1360-\end{array}$ & $\begin{array}{r}{ }^{-} \\
2.1196- \\
- \\
6.8704- \\
9.4556\end{array}$ \\
\hline جيد & متوسط & $\begin{array}{c}-1.82979- \\
21.31307^{*} \\
16.97284^{\star}\end{array}$ & $\begin{array}{l}9.17683 \\
7.30562 \\
4.45248\end{array}$ & $\begin{array}{l}.842 \\
.004 \\
.000\end{array}$ & $\begin{array}{r}- \\
19.9718- \\
6.8704 \\
8.1706\end{array}$ & $\begin{array}{r}16.312 \\
2 \\
35.755 \\
8 \\
25.775\end{array}$ \\
\hline ممتاز & متوسط & $\begin{array}{r}-18.80263- \\
4.34023 \\
-16.97284-\end{array}$ & $\begin{array}{l}8.91853 \\
6.97840 \\
4.45248\end{array}$ & $\begin{array}{l}.037 \\
.535 \\
.000\end{array}$ & $\begin{array}{r}- \\
36.4339- \\
-9.4556- \\
- \\
25.7751-\end{array}$ & $\begin{array}{r}- \\
1.1713- \\
18.136 \\
0 \\
- \\
8.1706-\end{array}$ \\
\hline
\end{tabular}

*. The mean difference is significant at the 0.05 level.

الخاتمة: Conclusion

اهتمت الدراسة الحالية بتناول أحد الموضوعات المهمة وهو موضوع العنف الموجه ضد الطلبة المر اهقين؛ أب

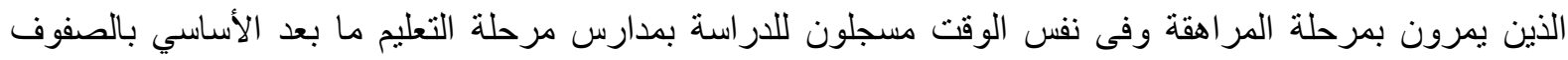
(12 - 11)، وقد طبقت على عينة قدر ها (145) مبحوثا من الذكور و الإناث، وقد تم تضمن الجزء الخاص بوصف علئ عينة الدراسة عرضا ممفصلا لكثير من البيانات المعرفة بالمبحوثين من الطلبة المراهقين. وقد اهتمت الدراسة بتناول هذه المرحلة العمرية " المر اهقة " لأهمية هذه المرحلة العمرية وتأثير ها على الأفراد ذلك التأثير الذي بمتذ لمر احل متأخرة

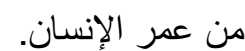

كما تناولت هذه الدراسة أحد الموضوعات المهمة وهو موضوع " العنف اللفظي " الممارس من قبل أولياء الأمور و المعلمين تجاه أولئك المراهقين. ويحاول الباحث ف هذا الجزء مناقتثة الإجابات التي تم التوصل إليها على أسئلة الدر اسة وفرضياتها. أما ما يتعلق بالسؤ ال الأول و الذي تمثل في " ما مستوى العنف اللفظي الذي يتعرض له الطلاب من قبل ولى

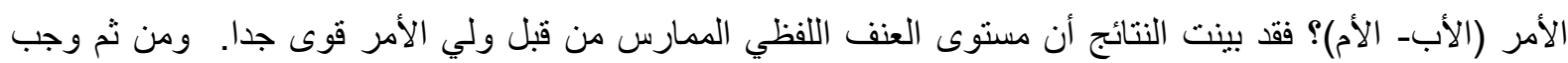
البحث عن السباب المؤدية لارتفاع العنف اللفظي الممارس من أولياء الأمور والذين تبين فيما بعد ارتباطه بالحالة العملية و المستوى التعليمي لأولياء الأمور، إذ بينت نتائج التحليل الاحصائي المتقدم وجود فروق إحصائية ذات دلالة معنوية 
تحدثها الحالة العملية لأولياء الأمور، كذللك وجدت فروق ذات دلالة معنوية أحدثها المستوى التعليمي حيث تبين أنه كلما

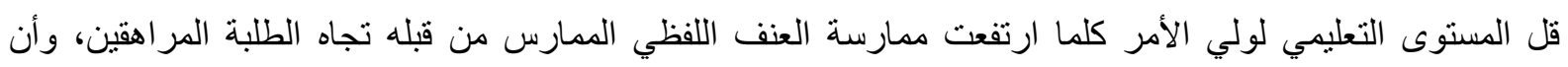

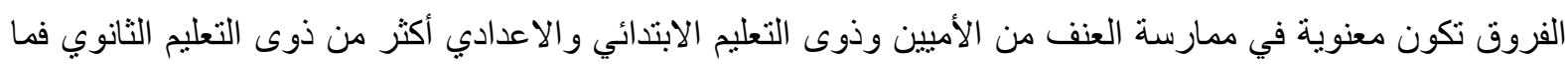
فوق، أي انه كلما ارتفع المستوى التعليمي لولى الأمر كلما انخفضت ممارسات العنف اللفظي الممارس منه تجان تلاه المر اهقين من أبنائه الطلية. وبناء عليه يرى الباحث وجوب تخصيص برامب ائه توعوية لهذه الفئات من أولياء الأمور لمساعدتهم على خفض مستويات العنف اللفظي الممارس منهم تجاه الأبناء المر اهقين.

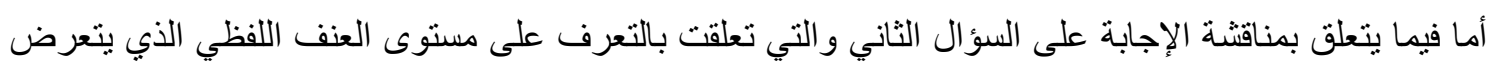

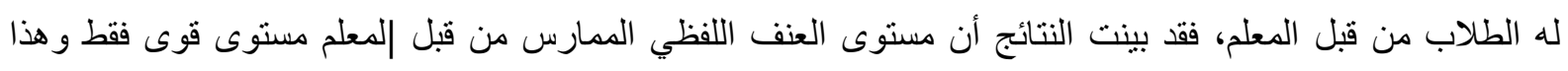
بخلاف مستوى العنف اللفظي الممارس من قبل ولى الأمر والذي وصف بالقوى جدا. و وعلى الرغم من الفارق في مستوى

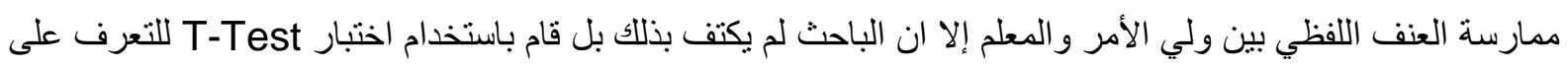

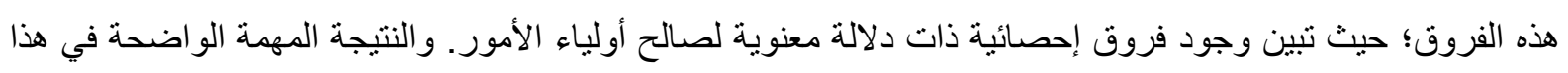
الإطار أن مستوى ممارسة العنف اللفظي مرتفعا سواء كان من قبل أولياء الأمور أو من قبل المعلمين.

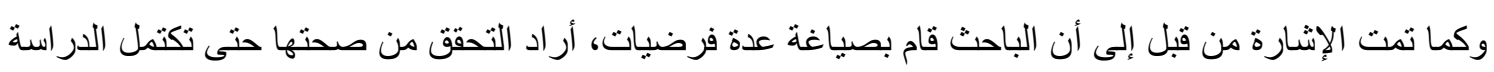
من حيث شكلها ومضمونها، لذا قام الباحث باختبار ها للتعرف على مدى وجود فروق احصائية في ممارسة العنف اللفظي

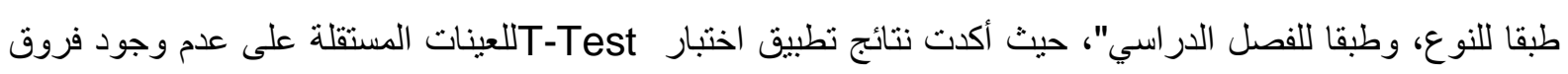
في ممارسة العنف اللفظي الموجه من أولياء الأمور و المعلمين تجاه المر اهقين من الطلبة طبقا للنوع وذللك في محور ولي علي الأمر ومحور المعلم وفى المقياس ككل. كما بين اختبار الفرضية الخاصة بالفروق الإحصائية طبقا للصف الدراسي وجود فروق إحصائية ذات دلالة

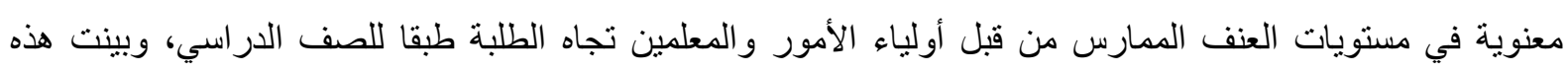

$$
\text { الفروق ان مستوى العنف اللفظي يمارس بطريقة أعلى تجاه طلبة الصف الثاني عشر. }
$$

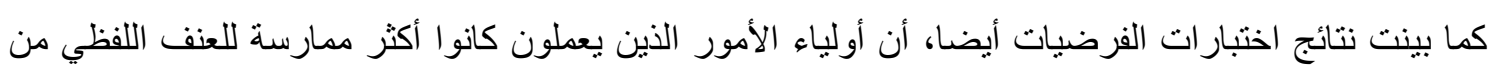

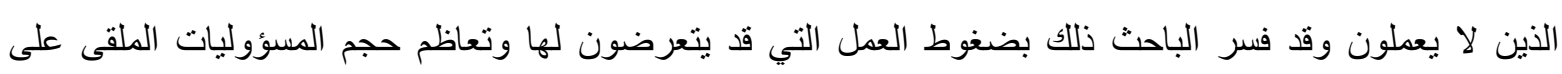
عاتقهم نتيجة لذلك.

كما تم إثبات صحة الفرضية القائلة " توجد فروق احصائية ذات دلالة معنوية بين متوسطات درجات الطلبة على لئى مقياس العنف اللفظي الموجه من المعلم طبقا للمستوى التحصيلي للطلبة المراهقين"، إذ تبين أنه كلما قل المستوى دله دئه التحصيلي للطالب كلما زاد استخدام العنف اللفظي من قبل المعلم تجاهه، حيث يرتفع مستوى استخدام المعلم للعنف اللفظي تجاه الطلبة ذب المستوى التحصيلي الضعيف والمتوسط بينما يقل تجاه الطلبة ذب المستوى الجيد و الممتاز. إن المناقثة السابقة تبين ارتفاع مستويات العنف اللفظي الممارس و الموجه ضد المراهين اهين والطلبة في محلة

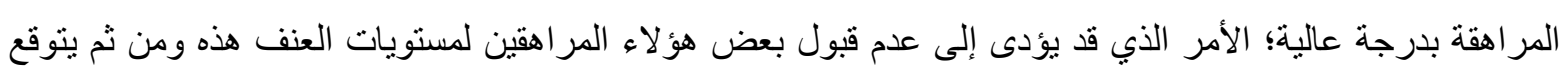

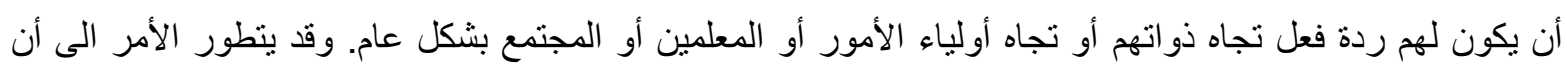

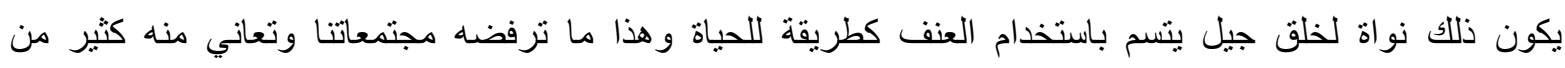
المجتمعات الإنسانية في الوقت الحاضر. 
وفى ضوء النتائج السابقة فإن الباحث يوصى بضرورة قيام الجهات المختصة في التعامل مع المر اهقين والطلبة بتصميم بر امج توعوية موجهة لأولياء الأمور و المعلمين بغرض العمل على تخفيف مستويات العنف اللفظية الممارسة تجاه المر اهقين و الطلبة في سن المر اهقة.

\section{مراجع الدراسة}

\section{أولا : المراجع العربية}

1- أبو الفضل جمال الدين ابن منظور ـ (9 . . ؟). لسان العرب (المجلد ץ). بيروت ـ لبنان: دار لسان العرب.

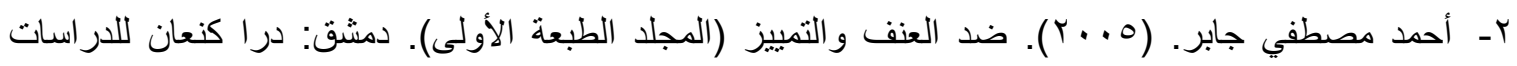
و النشر.

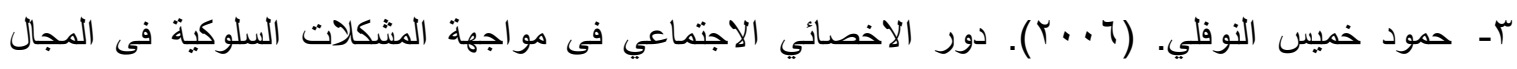
المدرسي. مسقط: جامعة السلطان قابوس.

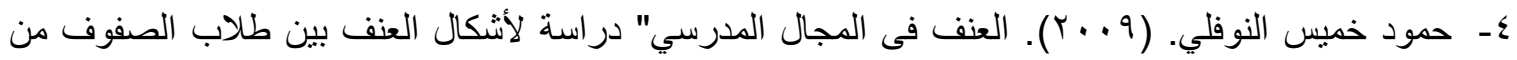

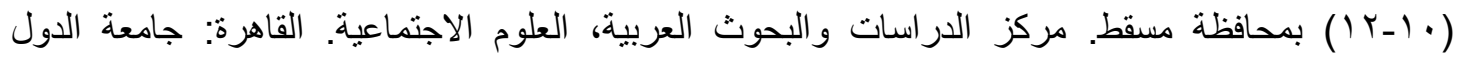

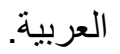

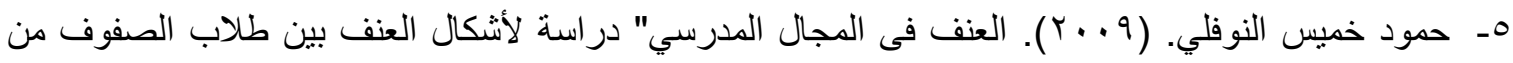
• ا__ ا بمحافظة مسقط. القاهرة: معهد الدر اسات و البحوث العربية- جامعة الدول العربية .



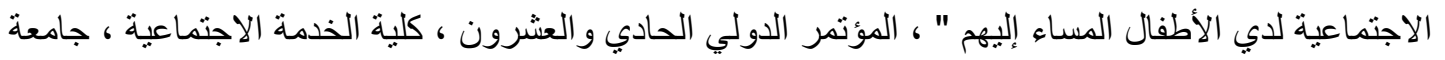

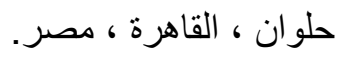

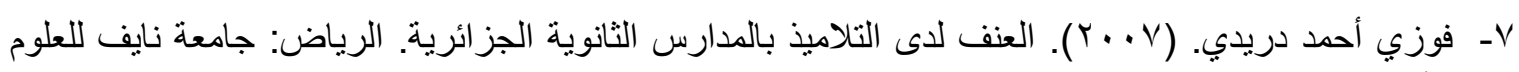
الأمنية.

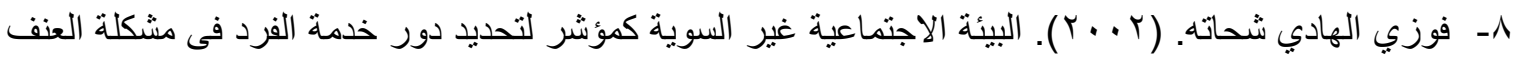

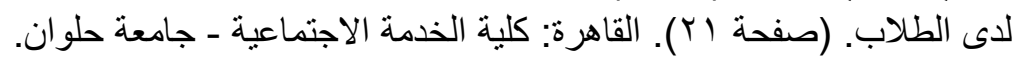

9- مايسة جمال أحمد. ( . . ب). العلاقات الأسرية وتأثير ها على ممارسة الأبناء للعنف- دراسة وصفية تحليلية

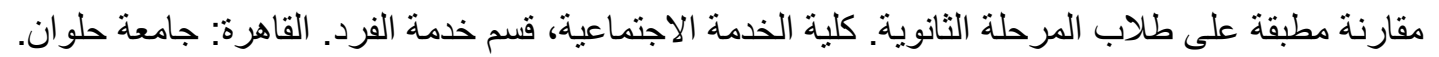

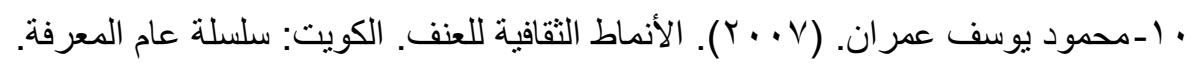

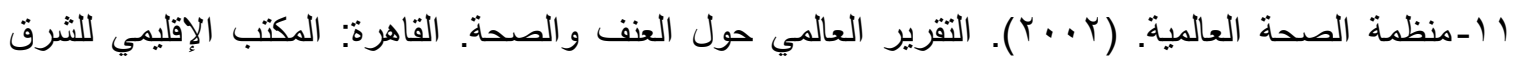
الاوسط. r ا ـ منير كر اشة. (9 . . r). العنف الأسري: سيكولوجية الرجل الضعيف و المر أة المعنفة. اربد- الأردن: عالم الكتب

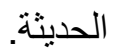

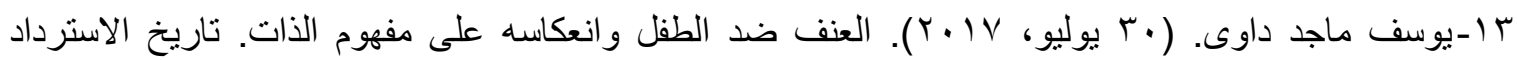

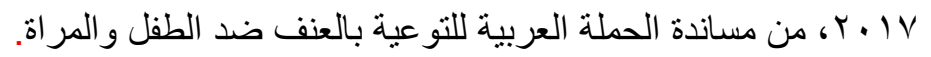


1- APA . $(Y \cdots r)$.Developing Adolescents: A Reference, the American Psychological Association for Professionals .Washington DC: the American Psychological Association .Retrieved april 28, 2015, from http://www.apa.org/pi/families/resources/develop.pd

2- http://www.musanadah.com/index.php?action=show_d\&id=172

3- Merriam-Webster. (2015). (An Encyclopædia Britannica Company) Retrieved april 27, 2015, from www.Merriam-Webster.com: http://www.merriamwebster.com/dictionary/adolescence

4- Pinheiro, P. S. (2006). World Report on Violence against Children. Unicef, Geneva.

5- Spano, Spano $(Y \cdots \varepsilon)$.Stages of Adolescent Development, Facts and findings .N Y: A collaboration of Cornell University, University of Rochester, and the New York State Center for School Safety .Retrieved Aay 22, 2015, from http://www.actforyouth.net/resources/

6- Unicef.$(Y \cdot 11)$.THE STATE OF THE WORLD'S CHILDREN 2011, Adolescence An Age of Opportunity .NY: United Nations Children's Fund (UNICEF) .Retrieved Jun 11, 2015 